HID 45 (2018)

\title{
LOS ESCRIBANOS PÚBLICOS DEL NÚMERO EN CÁDIZ SEGÚN EL PLEITO DE LA CIUDAD CONTRA DIEGO GONZÁLEZ
}

\author{
$(1514-1515)^{1}$
}

\author{
THE PUBLIC NOTARIES IN CÁDIZ ACCORDING TO THE LAWSUIT \\ OF THE CITY AGAINST DIEGO GONZÁLEZ (1514-1515)
}

\author{
María DolORES RoJAS VACA ${ }^{2}$ \\ Universidad de Cádiz \\ dolores.rojas@uca.es ORCID: https://orcid.org/0000-0002-1292-3748
}

RESUMEN: Aproximación al notariado público en el Cádiz de principios del XVI, a partir, en especial, de un pleito seguido en el Consejo Real por la ciudad contra el escribano real Diego González sobre la posesión de una escribanía de número local. El estudio se realiza en su doble vertiente, institucional y, en menor medida, documental y con preferencia desde la óptica de los documentos de la práctica sin desdeñar, no obstante, el marco legal. Así en lo institucional, se abordan aspectos tales como número de notarios ejercientes, nombramiento y acceso al oficio, tanto requisitos como vías oficiales con la casuística pertinente. En lo documental, se esboza el quehacer de los notarios a través de la visión de sus conciudadanos y, fundamentalmente, de los protocolos que confeccionaron y autenticaron.

PALABRAS ClAVE: Diplomática notarial moderna; notariado público; institución notarial; documentos notariales; pleito; Consejo Real; siglo XVI; Cádiz (Castilla).

ABSTRACT: Approaching the notary public in Cadiz at the beginning of the 16th century, especially after a lawsuit followed by the Royal Council of the city against the royal notary public Diego González on the possession of a local notary

Recibido: 21-5-2018; Aceptado: 18-6-2018; Versión definitiva: 21-6-2018.

1. Abreviaturas utilizadas: AGS $=$ Archivo General de Simancas; $\mathrm{AHPC}=$ Archivo Histórico Provincial de Cádiz; $\mathrm{ca}=$ circa $; \mathrm{CCA}=$ Cámara de Castilla; $\mathrm{CJH}=$ Consejo y Juntas de Hacienda; $\mathrm{CRC}$ $=$ Consejo Real de Castilla; Cuad $^{\circ}=$ cuaderno; $\operatorname{doc}(\mathrm{s})=$ documento(s); $\mathrm{L}=$ Ley; NR $=$ Nueva Recopi lación $; P=$ Partida $;$ PN = Protocolos Notariales; preg = pregunta; Prob = Probanza; RGS = Registro General del Sello; Tít $=$ Título.

2. Este trabajo ha sido financiado con cargo al Proyecto de Investigación de Excelencia de la Junta de Andalucia P07-HUM-02554, Notariado y documentación notarial en Andalucía.

Copyright: (C) Editorial Universidad de Sevilla. Este es un artículo de acceso abierto distribuido bajo los términos de la licencia de uso y distribución Creative Commons Reconocimiento-No-ComercialSinObraDerivada 4.0 (CC BY-NC-ND 4.0) 
office. The study is carried out in both its institutional and, to a lesser extent, documentary aspects, preferably from the point of view of practice documents, without, however, disregarding the legal framework. Thus, at the institutional level, aspects such as the number of notaries practising, appointment and access to the office are dealt with, as well as requirements and official channels with the relevant casuistry. In the documentary field, the work of notaries is outlined through the vision of their fellow citizens and, fundamentally, through the protocols they drew up and authenticated.

KEYWORDS: Modern notarial diplomacy; public notary office; notarial institution; notarial acts; litigation; Royal Council; 16th century; Cadiz (Castile).

En la sección Consejo Real de Castilla del Archivo General de Simancas se conserva un pleito que, iniciado en 1514, enfrenta, de un lado, a la ciudad de Cádiz y, de otro, al escribano real Diego González. Y todo ello por la posesión de una escribanía de número del lugar ${ }^{3}$.

Aunque incompleto, la información que ofrece acerca del notariado público gaditano en una época prácticamente desconocida ${ }^{4}$ invita a su estudio $\mathrm{y}$, cuando menos, parcial edición. Tal desconocimiento de seguro obedece a la carencia de actas capitulares y protocolos notariales que, de la ciudad y relativos al período que nos ocupa, padecen nuestros archivos locales, circunstancia en la que jugó un papel decisivo el asalto angloholandés de 1596. De ahí que este trabajo se realice, en ausencia de aquellas fuentes, sobre la base del material documental representado por la documentación emitida y, en su caso, recibida por la Cancillería regia castellana y por los Consejos asesores de la Monarquía, depositada en la actualidad en Simancas y organizada en las secciones Registro General del Sello, Cámara de Castilla, Consejo Real de Castilla y Consejo y Juntas de Hacienda. Por demás, dos registros notariales gaditanos, los más antiguos que se conservan anteriores a 1550 en el Archivo Histórico Provincial de Cádiz, posibilitan una aproximación a la práctica documental desarrollada por estos notarios.

\section{El Pleito CÁDIZ-GonZÁLEZ (1514-1515)}

En lo que ha llegado a nosotros el proceso se estructura en torno a cuatro cuadernos. El primero se abre con la portada del pleito. Reseña ésta la identificación de los litigantes, el objeto del litigio y los nombres del escribano de cámara y del relator. Tras la portada registra documentación de índole varia, fundamentalmente la presentada por las partes ante el Consejo Real para definición de sus posturas y

3. AGS, CRC, 24, 7.

4. Algunas referencias nominales y cronológicas relativas a notarios gaditanos actuantes en el siglo XV y en los comienzos del siglo XVI en Antón Solé, Ravina Martín 1975, pp. 171-182; Sánchez Herrero 1981, pp. 178-179; Martín Gutiérrez 2006, pp. 218, 220. 
defensa de sus intereses. Consiste en memoriales, peticiones y escritos alegatorios. A ellos se suman otros documentos que los justifican tales como, entre otros, las copias certificadas de las sesiones capitulares donde se gestaron los hechos. Recoge también escritos relativos a los trámites inherentes a la dinámica del proceso cuales son apuntes sobre citaciones, notificaciones, recepción a prueba, publicación de éstas y, por supuesto, algunas sentencias.

Los tres cuadernos restantes contienen probanzas de testigos. En los cuadernos segundo y tercero se asientan probanzas de interrogaciones de los testigos presentados por la ciudad y por Diego González respectivamente. El último consigna la probanza de posiciones realizada a instancia del mismo Diego González .

\subsection{Hechos, peticiones y alegaciones}

El detonante del pleito lo constituye la negativa del ayuntamiento a recibir como escribano público del número de Cádiz a Diego González y, en consecuencia, a aceptarlo como tal notario. En efecto, en cabildo de 6 de noviembre de 1514, comparece González ante Alonso Sánchez de la Vera, teniente del corregidor Pedro de Bazán, y ante los regidores Antón Bernalte, Polo Bautista de Negrón, Cristóbal Marrufo, Cristóbal Cabrón, Diego Sánchez de Cádiz, Martín de Haya y Fernando de Cubas, todos en presencia de Diego Sánchez, teniente del escribano de cabildo Fernando Gascón. Presenta carta de merced por la cual la reina doña Juana le concede, con carácter vitalicio, una escribanía de número de Cádiz por renuncia de Cristóbal Arias, su anterior titular ${ }^{6}$. Presentado el documento, pide a las autoridades que lo cumplan. Siguiendo el protocolo habitual, justicia y regidores toman en sus manos la carta de merced, la besan y colocan sobre sus cabezas en señal de respeto y reverencia.

A continuación, el teniente manda a los regidores que voten sobre el particular. Todos obedecen pero, en lo que respecta al cumplimiento ${ }^{7}$, mientras unos difieren para una sesión posterior su respuesta, ${ }^{8}$ otros se suman al voto del regidor Cristóbal Marrufo ${ }^{9}$. Éste se muestra abiertamente contrario a su recepción, arguyendo que González es clérigo de corona y que ha accedido al oficio mediante compra por lo cual, y hasta que la reina dictamine, Marrufo contradice y suplica de los efectos de la "provisión" real.

En 8 de noviembre, en presencia del escribano de cabildo y ante el teniente del corregidor, comparece nuevamente el regidor Marrufo, alegando de forma pormenorizada las razones de su voto en contra según los términos que exponemos a continuación:

5. Sobre la probanza de posiciones y su diferencia con la de interrogaciones, García Goyena, Aguirre 1841, vol. 6, Tít 72, p. 68.

6. Apéndice, doc nº 3 .

7. González Alonso 1980, pp. 469-488 y Tau Anzoátegui 1980, pp. 55-110.

8. Es el caso de los regidores Antón Bernalte, Polo Bautista de Negrón y Fernando de Cubas.

9. Es el caso de los regidores Cristóbal Cabrón, Diego Sánchez de Cádiz y Martín de Haya. 
... Lo primero porque el dicho ofiçio fue conprado públicamente por lo qual es perdido e no puede vsar dél conforme las leyes e premátycas de estos reynos.

Lo otro porque es contra los vsos e buenas costunbres e cartas e provisyones de su alteza que esta çibdad tyene por las quales confyrma los ofiçios de regymientos y escryuanías en los veçynos e fijos de vezynos e naturales desta dicha çibdad y, no lo seyendo el dicho Diego Gonçález, no puede ser al dicho ofiçio de escryuanía reçebido.

Lo otro porque es en oprobio y menospresçio desta dicha çibdad porque seyendo, como es, esta çibdad tan noble e tan antygua que aviendo seýdo en ella syenpre los escriuanos //5r públicos de los más honrrados e prinçipales de ella concurryendo de todas partes del mundo a esta çibdad, sería grande vituperio e menospresçio el dicho Diego Gonçález ser escriuano público de ella seyendo como es christiano nuevo, onbre de baxa condiçión e pobre e de poca abtoridad, seyendo el dicho ofiçio de tanta fidelidad que no se deve dar saluo a personas que por cosa del mundo no se pueda presumir que en él faga cosa que no deva.

Lo otro porque la cabsa que a Christónal Arias movió a renusçiar el dicho ofiçio en el dicho Diego Gonçález fue porque el dicho Christóual Arias fizo vn codeçilio de vna Elvira Estopiñán, la qual avía vn año que no hablava por razón de çierta enfermedad que tenía de que murió y en las palabras del dicho codeçilio el dicho Christóual Arias dio fee que estava en su seso e que por su propia boca lo avía fecho estando ella que no hablava, como dicho es, e porque sobre el dicho codeçilio andavan en pleyto y estava provado la dicha Elvira Estopiñán no hablar a esta cabsa por este yerro que el dicho Christóual Arias avía fecho, conosçiendo tener perdido el dicho ofiçio, lo renusçió en el dicho Diego Gonçález, el qual dicho Diego Gonçález fue testygo del dicho codeçilio y lo escryvió, por donde se presume que fue partýcipe en el dicho yerro con el dicho Christóual Arias.

Lo otro porque el dicho Diego Gonçález es clérigo de corona, la qual ha traýdo abierta e seyéndolo tiene perdido el dicho ofiçio e sy lo vsase tiene las penas contenidas en las leyes e premáticas de su alteza.

Lo otro porque el dicho ofiçio es acreçentado que antygua-//svmente no solía aver saluo tres escriuanos públicos en esta çibdad e agora ay siete e a cabsa de estar esta çibdad tan pequeña no se pueden sustener ni mantener los dichos escriuanos ${ }^{10}$.

Finalmente, en cabildo de 9 de noviembre ante el lugarteniente, los regidores asistentes, a saber, Antón Bernalte, Polo Bautista de Negrón, Rafael Fonte, Diego Sánchez Bernalte, Diego Sánchez de Cádiz, Cristóbal Cabrón y Simón Gentil, en presencia del escribano Diego Sánchez, proceden a la votación definitiva. Todos los regidores, sumándose al voto de Marrufo, unánimemente, contradicen y suplican. El teniente de corregidor, visto el resultado de la votación y cierta información que le fue presentada, según la cual el oficio fue acrecentado y vendido, así como el excesivo número de escribanías existentes en la ciudad que apenas si permitía mantenerse a sus titulares, decide suplicar de la provisión real y suspender la recepción de González hasta tanto la reina determine lo que se debe hacer ${ }^{11}$.

10. AGS, CRC, 24, 7, Cuad $^{\circ} 1$, ff. 4v-5v.

11. Copias certificadas notariales de las sesiones capitulares en cuestión en Ibid., ff. 2r-6v, ff. $11 \mathrm{r}-15 \mathrm{v}$. 
En consecuencia, los cabildantes consideraban que González no debía ser admitido al uso del oficio pues carecía de gran parte de los requisitos personales y morales exigidos a todo aspirante a notario. Entendían, además, que había accedido al oficio de manera fraudulenta por cuanto, de un lado, se trataba de una escribanía acrecentada que, como tal, debió ser amortizada y, de otro, había sido adquirida a título oneroso mediante compraventa privada.

Pese a ello, el mismo día 9, González, haciendo caso omiso del acuerdo municipal, se presentaba en el poyo con el señor teniente a dar fee de todos los abtos judiçiales e estrajudiçiales que ante mí pasaren, conforme a la carta real, y le requería que no me lo contradiga, antes me aya por reçebido al dicho ofiçio pues su alteza así se lo envía a mandar ... ${ }^{12}$ En consulta elevada al Consejo el 6 de diciembre González explicaba su actuación sobre la base de los siguientes argumentos:

... E asý es que yo me presenté en la dicha çibdad e en el cabildo della e presenté la dicha carta a los dichos justiçia e regidores e les requerí con ella la cumpliesen, como en ella se contiene, como vuestra alteza lo mandava. Los quales non lo an querido ny quyeren fazer syn thener razón alguna que a ello les mueva, saluo por enemistad que me tienen algunos dellos que persodieron a todos los otros para desobedeçer el real mandado de vuestra alteza fingendo escusaçiones fribolas e cabsas falsas e dinas de mucho castigo, lo qual paresçe muy notoryamente ser enemistad capital e no deseo de seruir a vuestra alteza. E no contentos con esto yo, conforme a la dicha carta, tomé la posesyón de la dicha escrivanýa e me presenté en el lugar donde suelen los escriuanos estar en el abdiençia e començé a fazer abtos. E el bachiller de la Vera, tenyente de la dicha çibdad, juntamente con los escriuanos que ende estavan, me echaron por fuerça del dicho lugar muy ynjuriosamente, mandándomelo el dicho teniente e los dichos escriuanos poniéndolo por la obra ${ }^{13}$.

Por tanto, según González, las razones esgrimidas por las autoridades locales para impedirle el ejercicio del oficio son escusaçiones fribolas e cabsas falsas que forman parte de un plan urdido por enemistad para destruirle.

En cualquier caso, el teniente respondía al requerimiento de González reiterando su decisión de suspender el efecto de la "provisión" real y de negarle la recepción, habida cuenta de las cabsas justas que determinaron la suplicación de la ciudad. Establecía, pues, que no se asiente ni vse del ofiçio hasta que por su alteza sea determinada la dicha cabsa e vistas las cabsas de la suplicaçión, no consintiendo en sus protestaciones. Al mismo tiempo, mandaba al escribano del cabildo incorporar en la respuesta los motivos de la suplicación, transcripción literal, por otro lado, de los capítulos presentados por el regidor Marrufo. Ambos, requerimiento y respuesta con las razones referidas, figuran en un testimonio que el escribano municipal entregaba a González el 11 de noviembre ${ }^{14}$.

12. Apéndice, doc $n^{\circ} 5$.

13. Apéndice, doc $n^{\circ} 6$.

14. Apéndice, doc $n^{\circ} 5$. 
De todas formas, tres días después de presentar ante el Consejo el testimonio anterior, en 9 de diciembre, Diego González hacía lo propio con un escrito alegatorio donde, además de achacar defectos de forma a la suplicación realizada y al seguimiento de la misma, niega todas y cada una de las faltas que se le imputan al tiempo que defiende la legalidad de su conducta, ello del siguiente modo:

... Y respondiendo a ellas (i.e. razones de la ciudad) digo que la merçed que vuestra alteza me hizo del dicho ofiçio fue justamente hecha y el dicho Christóual Aryas, cuyo hera el dicho ofiçio, le renunçió en mí libremente, mas avnque yo le conprara dél no por eso tengo pena ny él en venderlo pues de derecho no está proibido ni ay premática que tal diga.

$Y$ en ser yo reçibido en el dicho ofiçio no se haze perjuizio a los buenos vsos de la çibdad de Cádiz porque no ay en ella priuilegio ni vso ni costunbre que los escriuanos sean della naturales, antes todos los escriuanos del número que ay en la dicha çibdad eçebto vno son estrangeros y Diego Sánchez, que es el procurador que sygue esta causa, vno de los dichos escriuanos, es natural de la çibdad de Xerez. Y avnque fuese verdad que la naturaleza se requiriesse naci yo en la dicha çibdad de Cádiz, syendo mi padre y mi madre allý vezinos.

No ay oprobio ninguno de la dicha çibdad en que yo sea escriuano del número della pues soy ábile e sufiçiente y niego yo ser christiano nueuo, antes al tienpo que yo nasçi mi padre e mi madre heran convertidos a nuestra Santa fee cathólica $y$ aún diez años antes. Y ésta que se allega no es causa bastante en derecho para quitarme a mi la merçed que vuestra alteza me tyene hecha pues en estos reynos no ay christiano que se pueda dezir nueuo.

Yo no soy ni nunca fuy de corona y afirmar lo contraryo es yntentar cabsas generales por donde se ynpida la merçed $/ /{ }^{19 v}$ que vuestra alteza justamente me tiene fecha. El dicho Christóual Arias nunca cometió delito por donde meresçiese ser priuado deste ofiçio y, avnque le cometiera, antes que por sentençia fuese pronusçiado pudo muy bien renunçiar el dicho ofiçio.

El dicho ofiçio de escriuanía no es acreçentado y, avnque lo fuera, pues el dicho Christóual Aryas fue reçebido a él yo no puedo ser escluso, espeçialmente, no vacando por muerte y la dicha çibdad se a perjudicado porque ha reçebido otros muchos [...] vacaçiones syn ayudarsse del dicho acresçentamiento ${ }^{15}$.

Y es que, en su opinión, es la animadversión que le profesan los regidores, en especial, Cristóbal Marrufo y su pariente y muy gran amigo, el escribano Fernán Sánchez de Alcaraz que, a su vez, lo era del resto de los cabildantes y del colectivo notarial $^{16}$, lo que le ha conducido a esta situación pues, como expone,

15. Apéndice, doc $n^{\circ} 7$.

16. En este sentido van las preguntas planteadas por González a sus testigos y a los de posiciones: “¿Saben que Christóval Marrufo, [vno de los] regidores de la dicha çibdad, por a[mor de Fernán Sánchez], escriuano della, que es su muy gran amigo, movió a los otros regidores a que contradixesen e diesen poder contra el dicho Diego Gonçález?” (Prob 2 y 3, preg 9, enunciado), “Saben que Fernán Sánchez de Alcaraz, vno de los escriuanos de la dicha çibdad, por ser como es muy amigo de todos los regidores de la dicha çibdad e, asymismo, de la justiçia anda de regidor en regidor rogándoles que sygan la dicha cavsa contra él. E que no hagan nada por el dicho Diego Gonçález que él e los otros escriuanos gastarán de sus faziendas contra él, lo qual asymismo fazen los otros escriuanos?" (Prob 2 y 3 , preg 13 , enunciado). 
...la verdad es que el dicho regimiento y teniente no se mouieran a contradezir esta merçed si no fueran movidos y rogados por vn Christóual Marrufo, que es vno de los dichos regidores, el qual tiene vn pariente muy çercano que es escriuano de la dicha çibdad y, por amistad que tiene al dicho escriuano y enem [istad que] tiene a mý, negoçió con los dichos regidores des[...] que contradixesen la dicha merçed y diesen un poder con [...] y los escriuanos se obligaron de enbiar aqui a est [a] [...] que lo sy[guiese a su] costa. Y anssý lo han enbiado y publican que allegan estos ca[pítulos] por ser reçibidos a prueua y traerme vn año en pleito hasta destruyrme, a lo qual vuestra alteza no deue mandar dar lugar. Por ello suplicaba a la reina que me mande dar la dicha sobrecarta con pena y, si las causas que allegan fueren verdaderas, quédeles su derecho a sa[lvo] para que lo sygan contra mý, que yo estoy presto destar con ellos a justiçia y padesçer las penas que la carta de vuestra alteza me ponen ${ }^{17}$.

Las alegaciones de una y otra parte no terminan aquí. Diego Sánchez, procurador de la ciudad, en un testimonio elevado al Consejo Real el 11 de diciembre, solicita de la reina que mande proveer a González de curador ad liten con quien se siga este pleito pues es menor de hedad e avn de diez e ocho años para que el juicio se sustancie debidamente ${ }^{18}$. A él respondía González que todo lo que pide y dize es a fin de dilatar ${ }^{19}$.

El 14 de diciembre, Diego Sánchez, en nombre de la ciudad, presentaba ante el Consejo un nuevo documento donde reiteraba las alegaciones contra González, concluyendo $^{20}$. Por su parte, el mismo González, en otra petición del 15, recusaba el alegato por haberse presentado con el pleito ya concluido, por considerar que no existe causa suficiente para despojarle del oficio y por reiterar lo expresado en otras peticiones antes realizadas por el regidor Cristóbal Marrufo y el teniente de la ciudad. Terminaba solicitando de la reina que pues el dicho pleyto está concluso, lo mande ver e determinar ${ }^{21}$.

\subsection{Probanzas y sentencias}

El 7 de febrero de 1515, los consejeros fallan recibir a prueba lo dicho y alegado por las partes, estableciendo el término de 80 días, después elevado a 120 , para hacerla efectiva y presentarla ante el Consejo Real al tiempo que conceden el mismo plazo para que se practique la prueba contradictoriamente ${ }^{22}$.

Las probanzas de testigos se suceden entre el 4 y el 22 de mayo. Van precedidas de la presentación ante la justicia local de una real provisión con diferentes mandatos. De esta suerte, en las dos primeras, con fechas distintas de 9 de marzo y 6 de mayo pero de igual contenido, se manda al concejo que ordene a los litigantes nombrar un escribano por cada parte ante quienes pasen las probanzas.

17. Apéndice, doc $n^{\circ} 7$.

18. AGS, CRC, 24, 7, $\mathrm{Cuad}^{\circ} 1$, f. 20.

19. Ibid., f. $22 \mathrm{r}$.

20. Apéndice, doc $n^{\circ} 8$.

21. AGS, CRC, 24, 7, $\operatorname{Cuad}^{\circ} 1$, ff. 24r.

22. Ibid., f. $26 \mathrm{v}$. 
Así, en 18 de abril comparece Juan de Jerez, en nombre de la ciudad, ante el teniente de corregidor y el escribano público Diego Ramírez de la Rúa. Mostrada la real provisión antes referida, asienta las preguntas por las cuales han de ser interrogados los testigos de la localidad de Cádiz, nombrando como escribano receptor al dicho Ramírez de la Rúa. En 20 de abril, Diego González, a instancia del teniente, nombraba por escribano para el mismo efecto a Gonzalo García. En diferentes días, 4, 7, 9, 16 y 22 de mayo, ante los escribanos nombrados, Diego Sánchez, procurador de Cádiz, presenta a sus testigos quienes, previo juramento, proceden a declarar ${ }^{23}$. En fin, el 23 de mayo, a instancia de Diego Sánchez, el teniente le manda dar la probanza signada, firmada, cerrada y sellada.

Por su parte, el 7 de mayo, Diego González, ante el teniente de corregidor y el escribano público Gonzalo García, mostrada la oportuna provisión, entregaba las preguntas por las que habrían de ser interrogados sus testigos y, asimismo, la carta de su examen con el fin de que les fuese mostrada. Durante los días 7, 11, 12 y 14 de mayo, ante los escribanos nombrados, los testigos, previo juramento, pasaban a prestar declaración ${ }^{24}$. El mismo 7, Diego González presentaba otra provisión de la reina, librada el 6 de marzo a petición suya, ordenando a Diego Ortiz de Cubas, Fernando de Cubas y Cristóbal Marrufo, regidores de Cádiz, y a Diego Sánchez, Fernán Sánchez de Alcaraz, Diego Ramírez de la Rúa, Lope de Medina y Francisco de Mayorga, escribanos públicos, los quales diz que son los que propiamente e a su costa siguen el dicho pleito, que respondan a los artículos y posiciones que les pusiere ${ }^{25}$. También entregaba las preguntas por las que serían interrogados los testigos de posiciones a quienes, durante el 8 y el 9 de mayo, se les tomaba declaración ${ }^{26}$. Finalmente, en 18 de mayo, obtiene ambas probanzas, signadas, firmadas, cerradas y selladas, siendo la de posiciones presentada ante el Consejo Real el 6 de junio ${ }^{27}$.

Evidentemente, el contenido de las preguntas y de las declaraciones de los testigos se inclina en favor de la parte representada, haciendo hincapié en los as-

23. Los testigos llamados por la ciudad en la primera probanza son 15: Cristóbal Gentil (60 años), Rodrigo Alonso, guantero (50), Bernardo Arias (52), Pedro Buenhijo (55), Juan Rodríguez Buscavida (44), Fernando Suárez (60), Antón Machorro (60), Diego Sánchez Atalaya (65), Juana Bernal (36), viuda del comendador Bartolomé Estopiñán, Beatriz Bernal (40), viuda de Francisco de Estopiñán, Juana García (78), viuda de Diego López, Cristóbal de Escobar (42), Francisco Baldoýn, mercader inglés (37), Andrés de Castro (40) y Miguel Sánchez (40), todos vecinos de Cádiz. La probanza en AGS, CRC, 24, 7, $\mathrm{Cuad}^{\circ}$ 2, ff. 1r-17r.

24. Los testigos llamados por González en la segunda probanza son 6: Fernando Suárez (60 años), Pedro de Cubas (45), Antón Machorro (60), Simón García (50), Juan Giner (60) y Cristóbal Cherino (30). La probanza en AGS, CRC, 24, 7, Cuad $^{\circ} 3$, ff. 1r-15r.

25. AGS, CRC, 24, 7, $\mathrm{Cuad}^{\circ} 4$, ff. 1r-2r.

26. Los testigos llamados por González en la tercera probanza de posiciones son 8: Diego Sánchez, Fernán Sánchez, Diego Ramírez de la Rúa, Francisco de Mayorga y Lope de Medina, escribanos públicos, Diego Ortiz de Cubas, Fernando de Cubas y Cristóbal Marrufo, regidores. El deterioro del documento nos priva de las declaraciones del escribano Francisco de Mayorga y del regidor Marrufo. La probanza en AGS, CRC, 24, 7, $\mathrm{Cuad}^{\circ}$ 4, ff. 1r-19v.

27. Según anotación consignada en ibid., f. 5r. No consta la fecha de presentación ante el Consejo Real de la primera ni de la segunda probanza. 
pectos más favorables a sus respectivos intereses o, en su caso, más desfavorables para la parte contraria.

De este modo, las preguntas realizadas a los testigos de la ciudad giran alrededor de su conocimiento en torno a los siguientes temas:

- Vecindad del encausado.

- Estado clerical.

- Número limitado de oficios notariales en Cádiz.

- Oficio acrecentado.

- Exceso de número de oficios.

- Confesión religiosa.

- Cristiano nuevo y mozo de baja suerte y calidad.

- Renuncia de Cristóbal Arias en favor de González por falsedad.

- Implicación en falsedad de González.

- Renuncia del oficio de Arias por dinero.

- Pública voz y fama ${ }^{28}$.

Por su parte, las cuestiones planteadas a los testigos de González, tanto en la probanza de interrogaciones como en la de posiciones, iguales aunque los protagonistas sean distintos, versan sobre su conocimiento de los siguientes aspectos:

- Conocimiento de la merced por renuncia.

- Renuncia sin presión del antecesor.

- Escribanos de Cádiz todos forasteros.

- Habilidad y suficiencia con exhibición de carta examen.

- Padres cristianos conversos antes de nacer González.

- Antecesor hasta renuncia no condenado por delito ni privado de oficio por sentencia.

- Oficio de antecesor no acrecentado ni renunciado sin derecho.

- Animadversión del regidor Marrufo, instigador de regidores y escribanos.

- Pleito seguido a costa de los escribanos con intención de destruir sin intervención de la ciudad.

- Declaración de Diego Sánchez, aún conociendo de la justicia de González, que antes que la alcanzase tenía que ser destruido y que la causa se seguía a costa de los escribanos públicos.

- Manifestación del saber, habilidad y suficiencia de González.

- Fernán Sánchez, amigo de regidores y justicia, instigó en su contra; ¿a qué regidor han rogado los escribanos para que sigan la causa contra él?

- Fernán Sánchez y escribanos rogaron a quienes apoyaban a González que lo desfavorecieran a fin de dañarle.

- Fernán Sánchez y los escribanos se obligaron de librar de riesgo a la ciudad de la suplicación contra la merced real a González.

- Pública voz y fama ${ }^{29}$.

28. AGS, CRC, 24, 7, $\mathrm{Cuad}^{\circ} 2$, ff. 2v-3r.

29. AGS, CRC, $24,7, \mathrm{Cuad}^{\circ} 3$, ff. $3 \mathrm{v}-5 \mathrm{v}$ y $\mathrm{Cuad}^{\circ} 4$, ff. $2 \mathrm{v}-4 \mathrm{r}$. 
El 12 de junio, a petición de González y aún con la negativa de la ciudad, los consejeros mandan publicar las probanzas y las escrituras presentadas en el pleito, así como dar traslado a las partes para que aleguen de su derecho dentro del oportuno término legal.

Un día después, el 13 de junio, Diego González, además de presentar ante el Consejo el título de escribano real ${ }^{30}$ y una fe notarial de la toma de posesión de Cristóbal Arias, su antecesor, por renuncia de Rodrigo de Arenas ${ }^{31}$, exhibe una petición en los siguientes términos:

...vistas las prouanças e testigos por mí presentados en el pleyto...se hallará mi yntençión bien e conplidamente prouada por testigos mayores de toda eçebçión, dinos de fee e con escrituras bastantes por donde paresçe que, por renunçiaçión de Christóual Arias, vuestra alteza me hizo merçed de la escriuanía del número de la dicha çibdad...E yo soy ábil e sufiçiente para regir el dicho ofiçio. Los dichos escriuanos no hizieron prouança ninguna avnque tomaron el término de la ley de los çiento e veynte días e que todo su fin a sydo fatigarme con dilaçiones, creyendo que yo me dexaría de mi justiçia. Ninguna de las eçebçiones que pusieron es verdadera e asý viene confesado en las posyçiones por las dichas partes adversas en lo de la naturaleza e en ser yo hijo de personas crhistianas.

Por ello solicita de la reina que ordene dar su intención por bien probada y la de los adversos por decaída y en la sentencia tenga consideración a los muchos gastos que yo sobresto he fecho para que me los paguen los dichos escriuanos por cuya maliçia he fecho los dichos gastos ${ }^{32}$. Además, pide a la reina que mande al registro darle traslado signado de la carta de esamen con la intención de presentarla en el proceso. Los consejeros, en fin, dan el pleito por concluso.

En el reverso de la referida petición, una mera anotación, fechada el 25 de junio, indicaba cómo los consejeros Oropesa, Carvajal, Santiago, Águirre y Sosa, vista aquélla, mandaban que se le diese sobrecarta de la carta de merced del oficio, no obstante la suplicación de la ciudad y de las razones esgrimidas por ésta ${ }^{33}$.

La orden se formalizaba en una sentencia dada en Burgos el 28 de junio. Por ella fallaban

...que la dicha çibdad de Cádiz ni su procurador en su nonbre no prouaron su yntençión e demanda ni cosa alguna que les aprouechase e damos e pronunçiamos su yntençión por no prouada. E que el dicho Diego Gonçález prouó bien e cunplidamente sus exeçiones e defensyones e todo aquello que provar le convenía e damos e pronunçiamos su yntençión por bien prouada. Por ende, que devemos mandar y mandamos que, syn embargo de la suplicaçión que por parte de la dicha çibdad de Cádiz fue ynterpuesta, se dé sobrecarta al dicho Diego Gonçález de la merçed que le fue fecha por la reyna nuestra señora del dicho ofiçio de escriuanía sobre que es este dicho pleito para que lo vse y exerça conforme a la dicha carta de merçed.

30. Apéndice, doc $n^{\circ} 4$.

31. Apéndice, doc $n^{\circ} 2$.

32. AGS, CRC, 24, 7, Cuad $^{\circ} 1$, f. 34r.

33. Ibid., f. 34v. 
E por algunas cavsas que a ello nos mueven no hazemos condenaçión de costas contra ninguna de las partes, salvo que cada vna de ellas se pare a las que fizo. E por esta nuestra sentençia defynitiva, juzgando asý, lo pronunçiamos e mandamos en estos escritos e por ellos.

Firmada por el doctor Oropesa y los licenciados Santiago, Aguirre y Sosa era notificada a los litigantes en 29 de junio ${ }^{34}$.

El 9 de julio, González recurría la suplicación de la sentencia interpuesta por Alonso Romano, nuevo procurador de $\mathrm{Cádiz}^{35}$, y el 16 los consejeros Oropesa, Zapata, Carvajal, Santiago, Sosa y Cabrero confirmaban el fallo judicial, no obstante la suplicación de la ciudad, al tiempo que condenaban en costas a los particulares que siguieron el pleito ${ }^{36}$

Esta sentencia, pese a las recusaciones de las autoridades locales, quedó firme como demuestran la ejecutoria librada ordenando su ejecución ${ }^{37}$ y la actuación posterior de González como tal escribano del número de Cádiz ${ }^{38}$ hasta que, el 25 de junio de 1542, renuncia el oficio en Juan Barrera ${ }^{39}$.

\section{LOS ESCRIBANOS PÚBLICOS DE NÚMERO EN CÁDIZ A PRINCIPIOS DEL SIGLO XVI (1499-1542)}

El pleito que hemos examinado, además de aportar información sobre el caso concreto de este notario, se perfila como una fuente de primer orden para conocer, en líneas generales, el desarrollo del notariado público gaditano en los albores del siglo XVI. Naturalmente, muestra unas características similares a lo que conocemos de la práctica andaluza y, por extensión, de la castellana, en cuyo contexto cultural se encuadra ${ }^{40}$.

34. Ibid., f. $35 \mathrm{v}$

35. El 4 de julio Romano solicitaba la admisión y presentación en el proceso de una nueva probanza hecha por la ciudad como si se presentara en la primera instançia antes de la publicaçión ya que, aunque realizada en tiempo, no se presentó en su momento por culpa del retraso del correo que la llevaba al Consejo Real. Ambas, suplicación y recurso de la misma en AGS, CRC, 24, 7, Cuad $^{\circ} 1$, ff. $36 \mathrm{r} .-37 \mathrm{r}$.

36. Ibid., f. $37 \mathrm{v}$.

37. AGS, RGS, 1515, julio, 21.

38. En 1526 aparece en el pleito sostenido entre Cristóbal Díaz y Diego Ramírez de la Rúa sobre la revocación de una renuncia de escribanía, AGS, CRC, 87, 7 y CRC, 763, 1. Figura, igualmente, como escribano en las residencias tomadas a los corregidores gaditanos salientes de 1532 y $1535 \mathrm{y}$, asimismo, autoriza y testifica algunas matrices en los protocolos de Alonso de Medina, su hermano, de 1531,1538 y 1539 , cfr. infra 2.2 .

39. Anexo.

40. Sobre el notariado andaluz en la época que nos ocupa véanse para Sevilla, Pardo Rodríguez 1994, pp. 145-186; 1995, pp. 257-291; Rojas García 2014, pp. 17-45; para Córdoba, Ostos Salcedo 1995, pp. 171-256; para Granada, Obra Sierra 1995, pp. 127-170; Crespo Muñoz 2007, pp. 115-173; para Málaga, Arroyal Espigares, Martín Palma, Cruces Blanco 1991, 1995, pp. 47-73; Escalante Jiménez 2015, pp. 75-106; para Jerez de la Frontera, Rojas Vaca 1995, pp. 293-338; 2014, pp. 577-602. 


\subsection{Institución}

Como Diego González, los notarios gaditanos son de nombramiento real pues es el rey quien, mediante el correspondiente título, con carácter vitalicio, le constituye en el cargo y le confiere la auctoritas o potestad autenticadora ${ }^{41}$. Cádiz no gozó pues de la facultad de nombrar a sus notarios, como sucedía en otras ciudades de Castilla y, más concretamente, andaluzas cuales son Sevilla y Córdoba donde la nominación era comunal ${ }^{42}$. Ni siquiera disfrutó plenamente del uso de apresentar, esto es de proponer ante el rey a uno o a varios candidatos, lo que ocurría en Granada, Baza, Málaga y Jerez de la Frontera en caso de vacante por fallecimiento ${ }^{43}$. Sin embargo, y como se verá más adelante, parece que, por privilegio, uso y costumbre, al menos a fines del siglo XV, Cádiz tuvo la capacidad de elegir al pariente-sucesor del notario fallecido, elección que debía ser confirmada por el monarca ${ }^{44}$.

De otro lado, creemos en efecto que el número antiguo de escribanos en Cádiz fue de tres. En este sentido apuntan las declaraciones de los testigos de la ciudad para el período comprendido entre 1445 y 1490. No obstante, en 1514 la cifra ascendía ya a seis y en 1515 pasó a ser de siete. Los tres escribanos públicos más antiguos fueron Juan de Haya, Antón Romí y Sancho Benítez. A ellos se sumarían después Juan de Mar, o Amar, y Fernán Sánchez de Alcaraz. En 1515 los escribanos de número, incluyendo al encausado, eran Fernán Sánchez de Alcaraz, Diego Ramírez de la Rúa, Gonzalo García, Diego Sánchez, Francisco de Mayorga, Lope de Medina y Diego González ${ }^{45}$. Aludiendo al período más antiguo, algunos testigos mencionan haber oído que también eran escribanos Diego López y Juan Cestón ${ }^{46}$ pero indican que jamás les vieron usar los oficios ${ }^{47}$ :

...lo que sabe es que antiguamente solía aver tres escriuanos públicos en esta çibdad que heran Sancho Benitez e Juan de Haya e Fernand Suárez, padre deste testigo, e que oyó dezir que tanbién era en aquel tienpo escriuano público Juan Cestón pero queste testigo nunca le vido vsar el dicho ofiçio ni avía más de los que dicho tyene. E que sabe e a visto que agora ay seys escriuanos públicos desta dicha çibdad e que sy el dicho Diego Gonçález lo oviese de ser serían syete (Fernando Suárez, Pro. 1, preg 4).

De los requisitos personales y morales exigidos al aspirante a una escribanía pública en el Reino de Castilla ${ }^{48}$, en lo que hace al notario Diego González se

41. Bono Huerta 1982, vol. I-2, pp. 254-271.

42. Pardo Rodríguez 1995, pp. 258-260; Ostos Salcedo 1995, pp. 173-175.

43. Obra Sierra 1995, pp. 137-139; Crespo Muñoz 2007, p. 70; Arroyal Espigares, Martín Palma, Cruces Blanco 1995, p. 55; Rojas Vaca 1995, pp. 296-298; 2014, pp. 578-589.

44. Apéndice, doc $n^{\circ} 1$.

45. Prob 1-2, preg 4, constan las declaraciones sobre el tema en cuestión de los testigos de la ciudad y de los llamados por Diego González.

46. Anexo.

47. Prob 1, preg 4 (Diego Sánchez Atalaya).

48. P 3, Tít 19, L 2 . 
ponen en tela de juicio edad, religión cristiana, seglaridad, vecindad e idoneidad moral.

Cierto es que para acceder al cargo se precisaba la mayoría de edad, alcanzada habitualmente a los 25 años $^{49}$, pero este requisito no siempre se observó, en particular cuando el oficio se transmitía a un familiar o previa renuncia, considerándose entonces los 18 años como edad idónea ${ }^{50}$. En un momento dado del proceso, el procurador de la ciudad solicita a la reina que se provea a González de curador ad liten con quien se syga este pleito pues es menor de hedad e avn de diez e ocho años para que el juicio se sustancie debidamente ${ }^{51} \mathrm{y}$, en una de sus réplicas, insiste en que se trata de un muchacho de poca hedad ${ }^{52}$. Por su parte, el propio González afirma que tiene 21 años aproximados ${ }^{53}$. En cualquier caso, por acceder al oficio previa renuncia podría quedar dentro de los supuestos de hecho admitidos.

Respecto al requisito de religión, las Partidas, por un lado, imponían que los notarios fuesen cristianos ${ }^{54} \mathrm{y}$, por otro, establecían que los judeoconversos podían acceder a cualquier cargo público igual que los cristianos viejos ${ }^{55}$. Sin embargo, la "permisiva" legislación de Partidas se endureció durante los siglos XIV y XV, dado el sentimiento antijudío popular y al tiempo que tenían lugar las persecuciones y conversiones forzosas ${ }^{56}$. Los Reyes Católicos mandaron que ningún reconciliado ni hijo ni nieto de condenado por la inquisición pudiera usar ni tener oficios públicos, alcanzándoles la inhabilitación por vía femenina a un grado y por la masculina a $\operatorname{dos}^{57}$, lo cual reafirman en otra disposición ${ }^{58}$.

Aun cuando no nos consta que en González concurrieran tales circunstancias, es un hecho cierto que era hijo de judíos, llegados a nuestra localidad tras el destierro general de España, convirtiéndose antes o, más probablemente, después en cristianos $^{59}$. Si consideramos que Cádiz fue uno de los puertos de partida de la población judía durante la expulsión de 1492, cabe pensar que los padres de González, como otros de su credo, o, bien, se vieron obligados a elegir permanecer en la ciudad a cambio de la conversión forzosa o, bien, regresaron después a ésta huyendo de las duras condiciones del exilio que, inicialmente, habían "preferido" 60 . Por demás, caso de que su presencia fuese anterior a estos hechos, sería por buscar la seguridad dispensada por el gran don Rodrigo Ponce de León, el Marqués-Duque

49. Bono Huerta 1982, vol. I-2, pp. 212-214.

50. Ibid., pp. 212-213; Pardo Rodríguez 1994, pp. 155-156; 1995, p. 253; Ostos Salcedo 2014, p. 17

51. Petición de 1514, diciembre, 11, AGS, CRC, 24, 7, Cuad $^{\circ} 1$, f. 20 r.

52. Réplica del procurador de la ciudad presentada ante el Consejo en 1514, diciembre, 14, ibid., f. $23 \mathrm{rv}$.

53. Así consta en el enunciado de las Prob 2 y 3, preg 6.

54. P 3, Tít 19, L 2 .

55. $P$ 7, Tít 24, L 6 .

56. Carracedo Falagán 1990, pp. 62- 64.

57. $N R$ Lib 8, Tít 3, L 3.

58. NR Lib 8, Tít 3, L 4 .

59. Prob 1 , preg 7 y 8 .

60. Carrasco García 2006, pp. 326-328. 
de Cádiz conocido protector de los judios y conversos que habitaban en sus numerosos pueblos de señorío ${ }^{61}$ al tiempo que una salida expedita siendo necesario:

....sabe e es público que su padre y su madre del dicho Diego Gonçález eran christianos nuevos bueltos de judios al tienpo del destyerro general de los judios e avn dizen que primero pasaron a aliende siendo judios e después a oýdo dezir que se tornaron christianos (Rodrigo Alonso, Prob 1, preg 7).

...que el dicho Diego Gonçález es hijo de christianos nuevos e porque asý es la pública boz e fama, los quales syendo primero judios se tornaron christianos al tienpo que fueron desterrados los judios de España e que el dicho Diego Gonçález es avido e reputado por christiano nuevo por ser hijo de christianos nuevos de tan poco tienpo a esta parte (Pedro Buenhijo, Prob 1, preg 7).

Sea como fuere, la presencia de judeoconversos ejerciendo como escribanos no fue excepcional. Se constata, con frecuencia, en distintas poblaciones andaluzas y, en general, castellanas ${ }^{62}$ aunque, en el siglo XVI, existiera la conciencia social de que los judios, principalmente, ambicionaban los cargos de escribano para hacer más vulnerable a la comunidad cristiana ${ }^{63}$.

Volviendo al pleito, observamos cómo los testigos de la ciudad, atentos a su linaje judeoconverso, rechazan de plano su posible acceso al cargo notarial, entendiendo que constituye una afrenta para la localidad, un atentado contra su dignidad, honor y credibilidad, y hacen notar el descontento de parte de la población, la cual, recelosa de su condición, desconfiaría de la persona y de las escrituras que éste autorizara:

...porque en esta çibdad a avido de contyno por escriuanos públicos de ella e ay personas honrradas e que sería cosa muy ynjuriosa e afrentosa para tal çibdad como ésta que el dicho Diego Gonçález fuese escriuano público de ella porque es moço de baxa suerte e de muy poca autoridad e hijo de christianos nuevos que fueron primero judios. E queste testigo nunca ternía confiança ni se confiaría de las escripturas que el dicho Diego Gonçález hiziese (Rodrigo Alonso, Prob 1, preg 8). ...syendo como es el dicho Diego Gonçález christiano nuevo e hijo de christiano nuevo que primero fue judio e persona de muy baxa suerte sería cosa muy grave e ynjuriosa a esta çibdad que fuese escriuano público en ella e avn sobre ello murmurean <algunos> de los vezynos desta çibdad dizyendo que les paresçe muy mal que vn moço que ayer fue judio quiera ser oy escriuano público en vna çibdad tan noble e tan honrrada como ésta ... que cree que vernía mucho perjuizio al crédito desta çibdad sy el dicho Diego Gonçález fuese escriuano público e queste testigo nunca se confiaría en él ni yría a hazer escripturas con él (Bernardo Arias, Prob 1 preg 8).

61. Sancho de Sopranis 1953, pp. 321-323.

62. A modo de ejemplo véanse para Jerez, Ibidem, 342 y para Sanlúcar de Barrameda y Sevilla, Gil Fernández 2000-2002, pp. 485-515, 2003, pp 27-28; para Cármona, González Jiménez 2006, pp. 116-117 y Ramírez Barrios 2015, pp. 305-308; para Granada, Moreno Trujillo 2010, pp. 181-210; Moreno Sánchez 2015; para Córdoba, Extremera Extremera 2009; para Málaga, López Beltrán 2006, pp. 53-76; para Jaén, Porras Arboledas 2008a, 2008b; para Murcia, Martínez Carrillo 2002, pp. 597-609. Una visión de conjunto puede verse en Domínguez Ortiz 1991.

63. Carracedo Falagán 1990, pp. 63. 
...en esta çibdad sienpre a avido e ay escriuanos públicos de ella, onbres onrrados e de buen linaje e avidos por tales, e que sy el dicho Diego Gonçález oviese de ser escriuano público sería cosa muy ynjuriosa e grande afrenta a esta dicha çibdad por ser como es de linaje de los nuevamente convertidos de judios a christianos, los quales todos en esta çibdad son avidos e tenidos por gente de muy mala fama e malos fechos e que sabe e a visto en esta çibdad algunos de los vezinos e moradores de ella estar muy mal contentos en que el dicho Diego Gonçález procure el dicho ofiçio syendo del dicho linaje de los nuevamente convertidos (Antón Machorro, Prob 1, preg 8).

Por su parte, los testigos llamados por González inciden en el largo período de tiempo transcurrido desde el momento de la conversión de sus progenitores. En un testimonio se alude a su integración dentro de la sociedad cristiana gaditana, como se deduce del servicio en calidad de nodriza prestado por la madre al sobrino de uno de dichos testigos. Este argumento, sin embargo, resulta paradójico si asumimos que la conexión sangre-leche materna fue uno de los aspectos del pensamiento científico medieval que sirvió de fundamento intelectual a las leyes de limpieza de sangre y a las opiniones de los cronistas y teóricos españoles ${ }^{64}$ :

...dixo este testigo que él conosçió a su padre e a su madre del dicho Diego Gonçález e que puede aver veynte e dos o veynte e tres años, poco más o menos tienpo, e que ya entonçes heran avidos e thenidos por christianos pero queste testigo no los vió bavtizar más de quanto dezían que he[ran] christianos e que de antes quando eran judios [este testi]go no los conosçió e que su madre del dicho [Diego Gonçález] en aquel tienpo dava leche a vn sobrino deste testigo de la leche del dicho Diego Gonçález al qual entonçes criava (Simón García, Prob 2, preg 6).

... dixo este confesante que él lo vido naçer en esta çibdad de Cádiz y que heran su padre e su madre christianos convertidos en nuestra Santa fee católica y que benían en esta çibdad y estar por vezinos de ella a su padre e madre tienpo de veynte e seys años, poco más o menos, e que según su nasçimiento este confesante los a por naturales (Diego Ortiz de Cubas, Prob 3, preg 6).

Frente a las declaraciones contrarias González niega su condición de cristiano nuevo por cuanto, diez años antes de su nacimiento, más allá de treinta y un años, sus padres ya se habían convertido, afirmando que hoy en estos reinos no ay christiano que se pueda dezir nuevo ${ }^{65}$. Pero, como se ha señalado, la memoria colectiva y su capacidad para pervivir o desvanecerse resultó crucial para mantener la exclusión social de los conversos ${ }^{66}$.

La situación de seglaridad es, asimismo, cuestionada. Las Partidas prohibían el acceso a las escribanías de los clérigos ordenados para evitar que pudieran alegar inmunidad eclesiástica en caso de responsabilidad penal y así esquivar la justicia real ${ }^{67}$. Ostentar esa condición en el momento de la concesión del oficio

64. Edwards 1990, pp. 249-250.

65. Apéndice, doc $\mathrm{n}^{\circ} 7$.

66. López Belinchón 1998, pp. 271-290.

67. $P 3$, Tít 19, L 2 . 
o después conllevaba la pérdida del mismo tal cual consta en los títulos con que al presente no seáys de corona e sy en algúnd tienpo pareçiere que lo soys ansý mismo ayáis perdido e perdáis el dicho ofiçio ${ }^{68}$. Según los testigos de la ciudad, a González le vieron vestir loba o hábito clerical, algunos de continuo, reforzando así su condición de clérigo de corona o tonsurado ${ }^{69}$, cosa que él niega con rotundidad alegando que afirmar lo contraryo es intentar cabsas generales por donde se ynpida la merçed que vuestra alteza justamente me tiene fech $a^{70}$.

La vecindad en el lugar de ejercicio es otra exigencia legal ${ }^{71}$ a la que, según qué lugares, se suma la de naturaleza ${ }^{72}$. Para las autoridades locales sólo los vecinos, hijos de vecinos y naturales pueden acceder a regidurías y escribanías, conforme a los vsos e buenas costunbres e cartas e provisyones de su alteza que esta çibdad tiene ${ }^{73}$. Los testigos de la ciudad alegan que González ni es vecino ni hijo de vecino ni lo era al tiempo que le renunció el oficio Cristóbal Arias. Es más, algunos afirman que jamás le vieron por la localidad salvo desde los dos o tres años anteriores al proceso, siendo criado del anterior, y le tildan de extranjero o forastero ${ }^{74}$. En cuanto a los testigos aportados por González, los más coinciden en afirmar que los escribanos públicos gaditanos no son naturales de la población, sino venidos a Cádiz de otros lugares a usar los oficios aun cuando, mayoritariamente, estén casados en ella con naturales de la ciudad ${ }^{75}$. González, centrándose en la naturaleza, argumenta que no existe ordenanza ni uso alguno local según los cuales los escribanos de número deban ser naturales y que, en cualquier caso, él nació en Cádiz, siendo vecinos de ella sus progenitores. A mayor abundamiento, manifiesta que todos los notarios gaditanos coetáneos, salvo uno, son estrangeros. Por tanto, el requisito de vecindad, e incluso el de naturaleza, se debió desdeñar en Cádiz. Igual sucedía en otros territorios de Castilla, donde los notarios eran de creación real y no comunal ${ }^{76}$ :

...queste testigo se acuerda en esta çibdad de más treynta e çinco años a esta parte e nasçió en esta dicha çibdad e que el dicho Diego Gonçález no es veçino ni hijo de veçino desta dicha çibdad ni lo era al tienpo que acebtó la renusçiaçión que el dicho Christóval Arias le fizo e que sy fuera veçino o natural desta çibdad queste testigo lo supiera, antes sabe que es estranjero desta dicha çibdad e queste testigo nunca le conosçió en esta dicha çibdad syno de dos años a esta parte dende que estava con Christóval Arias (Juan Rodríguez Buscavida, Prob 1, preg 2).

...conosçe por escriuanos públicos desta çibdad a Diego Ramírez e a Diego Sánchez e a Gonzalo Garçía e a Fernán Sánchez e a Lope de Medina e a Françisco

68. Apéndice, docs $n^{\text {os }} 3$ y 4 .

69. Prob 1, preg 3 .

70. Apéndice, $\operatorname{doc} \mathrm{n}^{\circ} 7$.

71. P 3, Tít 19, L 2.

72. Bono Huerta 1982, vol. I-2, pp. 219-220.

73. Apéndice, doc $\mathrm{n}^{\circ} 5$.

74. Prob 1, preg 2 .

75. Como excepción se cita a Francisco de Mayorga que no tenía en Cádiz a su mujer, Prob 2-3, preg 4 .

76. Bono Huerta 1982, vol. I-2, pp. 219-220. 
de Mayorga, los quales todos no son naturales pero son vezinos e algunos dellos casados con mugeres naturales desta çibdad, los quales son Fernán Sánchez e Diego Sánchez e Gonzalo Garçía e Diego Ramírez (Cristóbal Cherino, Prob 2, preg 4). ...dixo que todos los escriuanos públicos que agora son en esta çibdad, que son este testigo e Gonçalo Garçía e Diego Ramirez e Fernán Sánchez e Françisco de Mayorga e Diego Sánchez, son casados en esta çibdad eçepto el dicho Françisco de Mayorga e queste testigo no naçió en esta çibdad ni vido naçer los otros más de quanto oyó dezir que son estranjeros e los más dellos son casados con naturales de Cádiz, los quales son casados Fernán Sánchez y Gonçalo Garçía e Diego Sánchez (Lope de Medina, Prob 3, preg 4).

La idoneidad moral o buena fama constituyó otro de los requisitos impuestos al aspirante a notario ${ }^{77}$. Efectivamente, este justificado y primordial requisito suponía la honradez legal y moral del candidato, lo cual implicaba estar ajeno de reprobación legal por motivo de infamia en la que incurre el condenado por falsario, y de reprobación moral por causa de vida obscena ${ }^{78}$. Al respecto, aun cuando González no había sido acusado de transgresión legal alguna, en calidad de testigo y escribiente participó del delito cometido por su antecesor. Al parecer, Cristóbal Arias incurrió en falsedad al autorizar un codicilo cuya otorgante, Elvira Estopiñán, además de muda, estaba mentalmente enajenada $\mathrm{y}$, en consecuencia, era legalmente incapaz ${ }^{79}$. Habiendo dado fe de que hablaba y estaba en su sano juicio, incumplió, pues, el deber de veracidad inherente a la función notarial por alterar la verdad de la sustancia del acto ${ }^{80}$. Ilustrativas resultan las declaraciones de los testigos que aporta la ciudad, entre quienes, además de describir con minucioso detalle las circunstancias que rodearon los hechos, no falta alguno que atribuye a ambos la comisión del delito en cuestión por razones económicas o, dicho de otro modo, por dineros que les dieron ${ }^{81}$ :

...dixo que lo sabe... es que el dicho Christóval Arias, siendo escriuano público, hizo el dicho testamento e codeçilio de la dicha Elvira Estopiñán en el qual dio fee que hablava e estava en su seso e queste testigo sabe que, al tienpo que hizo el dicho testamento e codiçilio e vn año antes, poco más o menos tienpo, estava sin habla la dicha Elvira Estopiñán que no hablava ni podia dezir cosa alguna ni estava en su seso ni entendimiento e questo que lo sabe porque este testigo tuvo en su casa a la dicha Eluira Estopiñán e la vido estar syn seso e ensuziarse en la cama e tomava en las manos la suziedad e hazía otras cosas como muger syn seso e asý lo estava al tienpo que el dicho Christóval Arias hizo el dicho codiçilio e queste testigo cree que por cabsa desto se fue el dicho Christóval Arias porque no le prendiesen o fizyesen otro mal e por esto renunçió el ofiçio en el dicho Diego

77. $P$ 3, Tít 19, L 2 .

78. Bono Huerta 1982, vol. I-2, p. 219.

79. $P 6$, introito, aunque la disposición se refiere al testamento, resulta aplicable también al codicilo, al afirmar que es "vna de las cosas del mundo en que más deuen los omes auer cordura quando lo fazen...porque en ellos muestran qual es la su postrimera voluntad e...porque, después que los han fecho, si se murieren, non pueden tornar otra vez a endereçarlos, nin a fazerlos de cabo".

80. Bono Huerta 1982, vol. I-2, p. 314-315.

81. Prob 1, preg 9, 10 . 
Gonçález porque ya se començavan a tomar testigos sobre ello ante Lope de Medina, escriuano público, ante el qual se tratava pleyto sobre el dicho codiçilio (Juana Bernal, Prob 1, preg 9).

...dixo que lo que sabe...es que al tienpo que el dicho Christóval Arias hizo el dicho codiçilio de que se haze minçión en la dicha pregunta e vn año antes, poco más o menos tienpo, la dicha Elvira Estopiñán estava syn habla e fuera de su seso e entendimiento e questo que lo sabe porque en todo el dicho tienpo la vido muchas e diversas vezes que tenía privada la lengua e no hablava ni podia hablar cosa alguna e le vido hazer locuras e rasgarse la camisa y otras cosas como muger syn seso e que a oýdo dezir que el dicho Christóval Arias hizo el dicho codiçilio dando fee cómo lo avía otorgado ella por su boca e en su seso e queste testigo sabe que es al contrario de la verdad por lo que dicho tiene de suso e questo es lo que sabe desta pregunta (Beatriz Bernal, Prob 1, preg 9).

...dixo que lo que sabe de la dicha pregunta es que al tienpo que la dicha Elvira Estopiñán fallesçió e vn año antes, poco más o menos tienpo, estava syn seso e muda que no hablava ni podía hablar cosa alguna e questo sabe porque la vido muchas vezes e le vido hazer locuras como muger syn seso e queste testigo algunas vezes le hablava porque hera su parienta e nunca la dicha Elvira le respondia ni podia responder porque, como dicho tiene, perdió la habla vn año antes que muriese de perlesýa que tenía e que lo que más dezýa era 'o', 'o', e nunca de aquí salía e que oyó dezir cómo el dicho Christóval Arias, syendo escriuano público, hizo vn codiçilio de la dicha Elvira Estopiñán e que dio fee como hablava e estava en su seso, lo qual es contrario de la verdad porque ni tenía seso ni hablava, como dicho tiene (Juana García, Prob 1, preg 9).

...dixo que la sabe...porque vido a la dicha Elvira Estopiñán, estando en casa del comendador, Bartholomé Estopiñán, que no hablava ni podýa hablar ni estava en su seso e queste testigo la vido muchas vezes levantarse en cueros y ensuçiarse en la cama e tomava en las manos la suziedad e lo llevava a la boca e hazýa otras locuras como muger syn seso e que dezýan los médicos que era perlátyca ${ }^{82}$ e que desta manera la vido vn año antes que fallesçiese que no podía hablar ni hablava, poco ni mucho, e quando quería comer lo pedía por señas e que cree que asý estava al tienpo del codiçilio que della hizo el dicho Christóval Arias e que el dicho Christóval Arias dio fee aver fecho el dicho codiçilio en su seso e por su boca syendo el contrario de la verdad. E sobre ello se trató pleyto e estava provada la dicha falsedad e que cree e tiene por çierto que a cabsa de la dicha falsedad, temiendo ser acusado della, renusçió el dicho Christóval Arias el dicho ofiçio en el dicho Diego Gonçález (Andrés de Castro, Prob 1, preg 9).

...dixo que ha oýdo dezir cómo el dicho Christóval Arias e el dicho Diego Gonçález, anbos a dos, avían fecho la falsedad del dicho codiçilio por dineros que les dieron. Fue preguntada a quien lo oyó e dixo que públicamente lo oyó a personas de cuyos nonbres no se acuerda (Juana Bernal, Prob 1, preg 10).

No menos clarificadoras son las afirmaciones de los escribanos-testigos de posiciones $^{83}$ :

82. Según el Diccionario de Autoridades, perlática "es el adjetivo que se aplica al sugeto o parte que padece la enfermedad de perlesía" y ésta es "resolución o relaxación de los nervios, en que pierden su vigor y se impide su movimiento y sensación".

83. Prob 3, preg 5 y 7. 
...dixo que antes el dicho Diego Gonçález no es sufiçiente para ser escriuano público e es de poca avtoridad y porque el dicho Christóval Arias hizo vn cobdeçillo de vna muger que no hablava e este testigo la vido e estava, demás de no hablar, fuera de seso e el dicho Diego Gonçález fue testigo del dicho cobdeçillo e lo escriuió (Fernán Sánchez, Prob 3, preg 5).

... dixo que sabe que el dicho Diego Gonçález sabe escriuir e hazer algunos contratos pero queste testigo no lo tiene por ábile ni por capaz para thener el dicho ofiçio, asý por ser como es público que es hijo de christianos nuevos como porque a oýdo dezir y es público que el dicho Diego Gonçález entervino en el yerro o maliçia o qualquier que fue del testamento que el dicho Christóval Arias hizo y aún este testigo a visto el testamento en el qual está por testigo el dicho Diego Gonçález (Diego Ramírez, Prob 3, preg 5).

...dixo queste testigo tiene al dicho Christóval Arias por buena persona pero que avía fecho çierto yerro en vna escriptura que hizo e otorgó vna mujer que mandó sus bienes a otra muger, la qual avía más de vn año que no hablava e dize la dicha escriptura que la otorgó la dicha muger, la qual escriptura escriuió el dicho Diego Gonçález que hera escriuiente del dicho Christóval Arias e que cree este testigo que el dicho Diego Gonçález le hizo hazer al dicho Christóval Arias la dicha escriptura. Preguntado por qué lo cree dixo que porque el dicho Christóval Arias hazía todo lo que el dicho Diego Gonçález le dezía en caso de escripturas (Lope de Medina, Prob 3, preg 7).

...dixo queste confesante no tiene al dicho Christóval Arias por buena persona por ser mudable y dezir vno y hazer otro y que no sabe ni a visto sy fue condepnado por sentençia en ningún delito, asý por razón del ofiçio como en otra manera (Diego Sánchez, Prob 3, preg 7).

Asimismo, parece que Arias incurrió en otro yerro más:

...dixo que antes es el contrario, que no es buena persona porque hizo aquel yerro e tanbién hizo vna vez vna provanza criminal e la ronpió e tornó a hazer otra e dello fue acusado pero queste testigo no a visto que fuese privado del ofiçio por sentençia ni tal a oýdo e menos cree que no se dio sentençia contra él en lo de la escriuanía e lo otro que lo niega (Fernán Sánchez, Prob 3, preg 7).

Al contrario, un testigo de posición-no escribano manifiesta que consideraba a Cristóbal Arias buena persona y desconocía que hubiera hecho algo indebido, salvo que sabía de oídas del eçeso cometido:

... dixo que él tenía e tuvo por buena persona al dicho Christóval Arias mientras vsó el dicho ofiçio de escriuanía e que si hizo alguna cosa que no deviera que lo no sabe, salvo que oyó dezir este confesante al tienpo que renunçió esta escriuanía que havía fecho çierto eçeso por donde mereçía perder el ofiçio del escriuanía e que a esta cavsa no lo podía renunçiar (Fernando de Cubas, regidor. Prob 3, preg 7).

Por otro lado, González, además de ser converso e hijo de conversos, gente de muy mala fama y malos fechos $\mathrm{y}$, cuando menos, de dudosa conducta legal, 
es, al decir de los testigos, persona de baxa suerte o condición, rahez ${ }^{84} \mathrm{y}$ de poca actoridad por cuanto se le vió que andava vendiendo en una arqueta por las calles çintas e tocas como persona de baxa suerte. Incluso refieren cómo un hermano suyo, Alonso de Medina, con el tiempo también notario ${ }^{85}$, se dedicaba a tales menesteres:

...e que a oýdo dezir e es público que el dicho Diego Gonçález andava vendiendo çintas por las calles e que a visto que oy en día vn hermano suyo que se llama Alonso de Medina anda vendiendo çintas e seda con una caxeta debaxo del brazo por las calles e que esto es verdad (Cristóbal Gentil, Prob 1, preg 8).

...dixo que la sabe en todo e por todo, segund que en ella se contiene, porque syenpre este testigo conosçió en esta çibdad por escriuanos públicos de ella personas muy honrradas e de quien se podia thener mucho crédito e que sería cosa muy ynjuriosa e de afrenta a esta çibdad e vezinos della que fuese escriuano público en ella el dicho Diego Gonçález, por ser tal como dicho tiene en la pregunta antes desta e porque es moço de muy baxa suerte e manera, e que sería mucho perjuizio que tuviese ofiçio público mayormente para dar fe syendo hijo de christianos nuevos e queste testigo no faría dél cosa alguna, antes sabe que en esta çibdad algunos ${ }^{86}$ vezinos della están escandalizados e les pesa mucho que el dicho Diego Gonçález procura de ser escriuano público syendo de la manera que dicho tiene (Juan Rodríguez Buscavida, Prob 1, preg 8$)^{87}$.

En fin, las autoridades locales y los testigos llamados por la ciudad subrayan lo inapropiado de su condición y conducta por entender que choca frontalmente con las cualidades que concurren en los escribanos públicos gaditanos, hombres de los más honrrados e prinçipales de Cádiz y que desempeñan el oficio con tanta fidelidad que por cosa del mundo no se pueda presumir que en él faga cosa que no deva. Por supuesto, tener un escribano público como González sería una deshonra y desprecio para una ciudad, como Cádiz, tan noble e tan antigua.

Los requisitos de aptitud, habilidad y suficiencia, suponían, de un lado, el dominio de la escritura aplicada a la redacción de los documentos y, de otro, poseer el saber jurídico preciso para la correcta formulación negocial de aquéllos ${ }^{88}$. Como se verá más adelante, baste decir aquí que González fue escribiente de su antecesor, al menos durante dos o tres años, con lo cual hemos de suponerle cierta práctica:

....sabe que el dicho Diego Gonçález es forastero e que nunca estuvo en esta çibdad syno syendo moço de Christóval Arias que escriuía con él que puede aver dos o tres años poco más o menos tienpo (Pedro Buenhijo, Prob 1, preg 2).

84. Según el Diccionario de Autoridades, rahez equivale a "baxo, humilde y abatido".

85. Alonso de Medina accede a una escribanía de número gaditana en 3 de marzo de 1520 por renuncia de Luis de León, Anexo.

86. Tachado: e; corregido, sobre muchos: "algunos".

87. Cfr., infra requisito de religión cristiana, declaraciones de Rodrigo Alonso y Bernardo Arias.

88. P 3, Tít 19, L 2 . 
...este testigo nunca vido en esta çibdad al dicho Diego Gonçález syno de dos años a esta parte syendo criado de Christóval Arias, escriuano público que hera desta çibdad (Diego Sánchez Atalaya, Prob 1, preg 2).

... dixo este testigo que vido la dicha carta de su alteza que le fue mostrada pero ques[te] testigo no sabe determinar sy es ábile e [sufiçiente] quanto sabe que sabe escriuir (Cristóbal Cherino, Prob 2, preg 5).

... seyéndole mostrada la dicha carta dixo que no sabe cosa alguna de lo contenido en la dicha pregunta más de quanto vee andar muy agudo al dicho Diego Gonçález (Antón Machorro, Prob 2, preg 5).

...la qual escriptura (i.e. codicilo) escriuió el dicho Diego Gonçález que era escriuiente del dicho Christóval Arias (Lope de Medina, Prob 3, preg 7).

En cualquier caso todas estas prescripciones debían ser verificadas, primero, con una información de la justicia local remitida al Consejo Real y, después, con el pertinente examen ${ }^{89}$.

Desde luego González llevó al Consejo la información en cuestión como pone de manifiesto la anotación Dio informaçión en forma que aparece en su título de escribano real ${ }^{90}$. Lo que desconocemos es el contenido del informe y la autoridad que lo certificó pues dudamos de que el mismo, dadas las circunstancias, procediera de las autoridades gaditanas. Un testimonio tardío muestra que tal información se podía recabar fuera del lugar donde el aspirante a notario iba a ejercitar el oficio. Es el caso de Hernando de la Cruz, natural de Sanlúcar de Barrameda, quien el 2 de octubre de 1568 comparecía ante el cabildo sanluqueño y solicitaba, por cuanto pretendía la merced de una escribanía de número de Jerez de la Frontera, además de una escribanía de los reinos, el informe positivo del ayuntamiento. A tal efecto exhibía, para su aprobación, las preguntas del interrogatorio de testigos en una probanza que, aún carente de respuesta testifical, mostraba el juicio favorable del corregidor ${ }^{91}$. Por demás, se trataba de una imposición exigida, asimismo, para acceder a otros oficios públicos con las lógicas diferencias inherentes al tipo de oficio pretendido ${ }^{92}$. Sea como fuere, es lícito pensar que nuestro notario eludiera a la justicia local buscando la información en otros lugares, habida cuenta, por otro lado, de que su presencia en Cádiz, al margen del período infantil, no iba más allá de los dos o tres años previos al pleito, según hacen constar algunos testigos ${ }^{93}$.

En lo que respecta al examen, la anotación Ábil es muestra que lo realizó y que fue hallado hábil por los consejeros, obteniendo, en consecuencia, el título de escribano de los reinos ${ }^{94}$, título que González denomina carta de examen y

89. Bono Huerta 1982, vol. I-2, pp. 228-240.

90. Apéndice, doc $n^{\circ} 4$.

91. Apéndice, doc $n^{\circ} 9$.

92. Poseemos también un ejemplo de 1557 relativo al cargo de regidor de Cádiz de Álvar Nuñez Cabeza de Vaca cuya probanza incorpora, además, los nombres de los testigos y sus pertinentes respuestas, AGS, CJH, 36-218.

93. Pedro Buenhijo y Diego Sánchez Atalaya, Prob 1, preg 2.

94. Apéndice, doc $n^{\circ} 4$. 
cuya data es veinticuatro días posterior al notarial ${ }^{95}$. En cualquier caso, el 7 de mayo, nuestro notario exhibe ante el teniente de corregidor la carta en cuestión con el fin de mostrarla a los testigos interrogados. Naturalmente todos confiesan haberla visto pero, en cuanto a la capacidad real del candidato, los testigos de la segunda probanza manifiestan, mayoritariamente, no saber si es hábil y suficiente para regir el oficio ${ }^{96}$. Los escribanos de número Fernán Sánchez de Alcaraz y Lope de Medina, testigos en la probanza de posiciones, declaran que no es suficiente, mientras Diego Sánchez y Diego Ramírez de la Rúa se pronuncian del modo que sigue:

... dixo que no sabe sy el dicho Diego Gonçález es ábil para ser escriuano público porque él no le a visto hazer escripturas, salvo que cree, según lo que a visto en él, que bien podría vsar del dicho ofiçio y que daría contento de algunas escripturas y que a visto vn título de notarýa de los reynos del dicho Diego Gonçález e que estas tales notarýas no se dan salvo a honbres que son ábiles (Diego Sánchez, Prob 3, preg 5).

...dixo que sabe que el dicho Diego Gonçález sabe escriuir e hazer algunos contratos pero queste testigo no lo tiene por ábill ni por capaz para thener el dicho ofiçio, asý por ser como es público que es hijo de christianos nuevos como porque a oýdo dezir y es público que el dicho Diego Gonçález intervino en el dicho yerro o maliçia o qualquier que fue del testamento que el dicho Christóval Arias hizo y avn este testigo a visto el testamento en el qual está por testigo el dicho Diego Gonçález (Diego Ramírez de la Rúa, Prob 3, preg 5).

Por su parte, el regidor Diego Ortiz de Cubas aporta su parecer al respecto:

...dixo este confesante que él se halló presente en la corte quando lo desaminaron los del Consejo e que oyó dezir este confesante a algunos señores de los del Consejo que hera ábile e sufiçiente y por algunas cosas queste confesante le vee fazer le paresçe que es ábile e sufiçiente para vsar el dicho ofiçio de escriuanía y queste confesante le vido sacar la carta de examen (Diego Ortíz de Cubas, Prob 3 preg 5).

Completando la declaración anteriormente formulada y contestando a la pregunta que se le plantea, Diego Sánchez reconoce haber afirmado que González sabía tanto en el dicho ofiçio de escriuano como se devía saber e que hera muy ábile e sufiçiente ${ }^{97}$. Mientras, los restantes testigos niegan o manifiestan desconocer tal afirmación ${ }^{98}$.

En otro orden de cosas, las vías oficiales de acceso al oficio fueron, como es habitual, la renuncia, la vacante y el acrecentamiento.

95. Apéndice, doc $n^{\circ} 3$.

96. Prob 2, preg 5.

97. AGS, CRC, 24, 7, $\operatorname{Cuad}^{\circ} 4, \mathrm{f} .4 \mathrm{v}$, enunciado de la pregunta 12.

98. Prob 3, preg 12. 
En caso de renuncia o traspaso en vida del oficio por el titular a favor de persona concreta ${ }^{99}$, supuesto mayoritario ${ }^{100}$, ésta debía cumplir las prescripciones legales al uso. Bajo pena de pérdida del oficio, que quedaría vacante y a disposición del monarca para su ulterior provisión, se establecía que el renunciante debía sobrevivir al menos 20 días a la fecha de otorgamiento de la renuncia ${ }^{101}$. Por su parte, el renunciatario quedaba obligado a presentar, de un lado, el título en el ayuntamiento en los 60 días contados desde su data ${ }^{102} \mathrm{y}$, de otro, la renuncia ante el Consejo dentro de los 30 días tras ser otorgada ${ }^{103}$. Tales condicionantes, recogidos en los títulos ${ }^{104}$, daban lugar, de ordinario, al otorgamiento de renuncias reiteradas y sucesivas con el fin de minimizar el riesgo que suponía la pérdida del oficio por exceder de los plazos legalmente estipulados ${ }^{105}$. Esto podría ser la causa de las varias renuncias otorgadas por Cristóbal Arias a favor de Diego González, una en Cádiz y el resto en El Puerto de Santa María:

... dixo queste testigo vido vna renunçiaçión que Christóval Arias hizo en el dicho Diego Gonçález en esta çibdad ante Françisco de Mayorga, escriuano público, y des ${ }^{106}$ supo que le hizo otras en la villa del Puerto de Santa María e que a oýdo decir que su alteza hizo merçed al dicho Diego Gonçález de la dicha escriuanía (Diego Ramírez, Prob 3, preg 2).

De no ser un error, al mismo fin de dilatar los plazos puede obedecer la forma en que está redactada la cláusula de los 20 días en la carta de merced de concesión del oficio notarial a Diego González. En efecto, en ella, la referencia para contar

99. Sobre los orígenes y significado de la renuncia y el devenir posterior de las mismas para Castilla, sin circunscribirlas a oficios concretos, véanse Tomás y Valiente 1970, pp. 125-139; 1982a, pp. 151-177. El mismo autor trata de nuevo el tema para Indias en Tomás y Valiente 1982b, pp. 35-139 y, especialmente, referido a los oficios de escribanías en Tomás y Valiente 1993, pp. 97-103. Asimismo, sobre la renuncia de las escribanías públicas del número para Castilla véanse Blasco Martínez 1990, pp. 85-87; Arroyal Espigares, Martín Palma, Cruces Blanco 1991, pp. 52-55; Pardo Rodríguez 1994, pp. 154-155; 1995, p. 272; Ostos Salcedo 1995, pp. 189-191; Obra Sierra 1995, pp. 140-142; Rojas Vaca 1995, pp. 300-301; 1996, pp. 35-37; Rojas García 2014, pp. 41-44; Domínguez Guerrero (2016), pp. $85-125$.

100. Anexo.

101. NR Lib 7, Tít 4, L 4. Según disposición de los Reyes Católicos en Toledo, año de 1480, 1. 60.

102. NR Lib 7, Tít 4, L 6. Pragmática dada por los Reyes Católicos en Granada a 24 de septiembre de 1501 .

103. NR Lib 7, Tít 4, L 5. Disposición dada por $\mathrm{D}^{\mathrm{a}}$ Juana en Burgos en 1515, confirmada por Carlos I en Valladolid en 1542.

104. Apéndice, doc $\mathrm{n}^{\circ} 3$.

105. Esta situación ya la observamos en Cádiz al respecto de los escribanos de número y de los procuradores y en Jerez de la Frontera para los escribanos del cabildo municipal en, respectivamente, Rojas Vaca 2006, p. 77; 2007, p. 450; 2010, p. 292. Asimismo, se ha detectado tanto en la ciudad de Sevilla para el reinado de Carlos I, Rojas García 2015, p. 43, como, para el reinado de Felipe II, en otras poblaciones de su tierra, Domínguez Guerrero (2016), pp. 97-105. Hernández Benítez 1995, p. 709 , recoge, para el caso de los regidores madrileños, algunas soluciones "chuscas" tendentes a soslayar la imposición legal de los veinte días que había de sobrevivir el renunciante para hacer efectivo el traspaso del oficio en el renunciatario.

106. Sic por después. 
los dichos 20 días de supervivencia del renunciante no es la fecha de otorgamiento de la renuncia, según marca la ley, sino la data del título en cuestión, lo cual es llamativo por cuanto la solución partiría de la propia Corona en connivencia con el encartado:

...la qual dicha merçed vos fago con tanto que el dicho Christóval Arias biva después de la fecha desta mi carta los veynte días que la ley dispone...Y que sy asý no lo fizierdes ayáis perdido e perdáys el dicho ofiçio e quede vaco para yo poder hazer merçed dél a quien mi voluntad fuere ${ }^{107}$.

La renuncia, por otra parte, debía tener carácter gratuito ${ }^{108}$. Sin embargo, con frecuencia, de no existir entre los implicados parentesco alguno podía encubrir un negocio anterior privado de carácter oneroso, un arrendamiento, una compraventa, etc., en cualquier caso, legalmente prohibido ${ }^{109}$. Esta circunstancia se dio en el caso de Diego González, según resulta de la declaración de las autoridades, de los testigos y del propio González aun cuando éste niegue que al comprar el oficio cometiera delito alguno pues Cristóbal Arias le renunçió en mí libremente mas, avnque yo le conprara dél, no por esto tengo pena ny él en venderlo pues de derecho no está proibido ni ay premática que tal diga ${ }^{110}$. Resulta llamativo el alarde de "ignorancia" legal de González, ilegalidad que, publicada con todo lujo de detalles por los testigos de la ciudad y denunciada por el ayuntamiento, a la postre y contra lo prescrito, será asumida por la misma Corona.

Harto expresivas, al respecto, son algunas de las declaraciones de los testigos de la ciudad ya que ponen al descubierto no sólo el carácter oneroso de la renuncia y del título de transmisión, la compraventa, sino también la forma de efectuar el pago del precio y el origen del dinero pagado, procedente, según se indica, de la comunidad conversa radicada en la localidad:

... a oýdo e es público que todos los christianos nuevos desta çibdad se juntaron e dieron dineros para que el dicho Diego Gonçález conprase la dicha escriuanía al dicho Christóval Arias por thener de su parte por escriuano otro christiano nuevo como ellos para sus cosas que suelen thener (Bernardo Arias, Prob 1, preg 8).

...dixo que sabe e a visto que el dicho Christóval Arias es mançebo de hedad de fasta treynta o treynta e çinco años, poco más o menos, e honbre sano e no enfermo e que a oýdo dezir e es público que renusció el dicho su ofiçio por dineros que el dicho Diego Gonçález le dio, lo qual es pública voz e fama en esta çibdad, e tanbién porque a oýdo dezir e es público que hizo vna falsedad en el testamento de que haze minción la dicha pregunta por cuyo temor se fue desta çibdad, según muchas presonas dizen. E este testigo asý lo cree porque, quando supo que se quería yr,

107. Apéndice, doc $n^{\circ} 3$.

108. NR Lib 7, Tít 2, L 8. Los Reyes Católicos, según pragmática dada en Madrid en 1494, "que prouee más estensamente en castigar a los que venden o compran los oficios que se han de dar por votos por los concejos y a los que los renuncian por dinero".

109. Id.

110. Apéndice, doc $n^{\circ} 7$. 
este testigo se maravilló porque estava ya heredado en esta çibdad e avía conprado vnas casas e hazýa otras (Antón Machorro, Prob 1, preg 11).

...dixo que sabe que el dicho Christóval Arias es mançebo de hedad de treynta e tres años, poco más o menos tienpo, a paresçer deste testigo e sano e no enfermo e que a oýdo dezir que el dicho Diego Gonçález conpró el dicho ofiçio por dineros del dicho Christóval Arias, lo qual a oýdo dezir públicamente, e es público en esta çibdad e que es verdad queste testigo fio a Alonso de Medina, hermano del dicho Diego Gonçález, en contýa de seys mill maravedies de paños que dél conpró. E después oyó dezir que fueron los dichos paños para dar al dicho Christóval Arias (Miguel Sánchez, Prob 1, preg 11).

....dixo que supo este testigo que por dineros que el dicho Diego Gonçález y vn su hermano dieron al dicho Christóval Arias e paños que conpraron de Françisco Balduýn e de otros ge la renunçió y no de otra manera e lo demás que lo niega (Fernán Sánchez, Prob 3, preg 3).

...dixo que lo que della sabe que puede aver ocho meses, poco más o menos tienpo, que Gerónimo Çenturión, corredor de lonja, dixo a este testigo que sy quería vender a Christóval Arias, escriuano público que fue desta çibdad, çiertos paños, que le saldrýan por la paga dellos Christóval de Bitoria e Miguel Sánchez e Symón Garçía e Alonso de Medina, hermano de Diego Gonçález, e queste testigo dixo que sí. E que es verdad que vendió çiertos paños al dicho Christóval Arias en cantydad de treynta e seys mill maravedies, poco más o menos, que le salieron por la paga los susodichos a plazo de diez e ocho meses en tres pagas, de seys en seys meses. E que oyó dezir e es público cómo los dichos maravedies eran para parte de pago de la escriuanía que el dicho Christóval Arias vendió al dicho Diego Gonçález. E por eso los susodichos salieron por la paga, por amor del dicho Diego Gonçález y, juntamente con ellos, el dicho Alonso de Medina, hermano del dicho Diego Gonçález, de mancomún (Francisco Baldoýn, Prob 1, preg 11).

En suma, aparte de la cuestión monetaria, el yerro, falta o maliçia cometido por Cristóbal Arias ${ }^{111}$ y el temor a ser condenado por ello motivaron, sin duda, la renuncia al oficio y su posterior huida de la ciudad. De otro modo, esta actuación resulta inexplicable al tratarse de un hombre joven, de entre 30 y 35 años, sano y arraigado en la localidad. Así lo estima, entre otros, Antón Machorro quien, como ya hemos visto, quando supo que se quería yr, este testigo se maravilló porque estava ya heredado en esta çibdad e avía conprado vnas casas e hazýa otras ${ }^{112}$.

La vacante, como vía de acceso al cargo notarial, podía tener lugar por fallecimiento del titular o por privación del mismo a causa de haber incurrido en algún delito. En caso de vacante por fallecimiento parece que en Cádiz, por privilegio, uso y costumbre, como sucede en otros lugares de Castilla ${ }^{113}$, estaba prevista la sucesión en el hijo, nieto o yerno del notario fallecido. De esta forma, al morir Pedro Galíndez, escribano público que fue de Cádiz durante mucho tienpo, Juan de Amar, su hijo mayor, era elegido y recibido como notario por los cabildantes, todos juntos a canpana tannida, a pesar de ser todavía menor de edad y, en con-

111. Cfr. supra requisito de idoneidad moral.

112. Prob 1, preg 11.

113. Pardo Rodríguez 1994, pp. 158-162; 1995, pp. 275-277; Ostos Salcedo 1995, p. 189. 
secuencia, de no poder ejercer el oficio por su persona. Sin embargo, cumplida la edad perfeta ${ }^{114}$, vuelve a solicitar su recepción por la ciudad y encuentra la oposición de las autoridades locales por lo cual solicita la intervención regia en el conflicto $^{115}$. Cabe pensar que ésta resultó efectiva y que, tras el 30 de septiembre de 1499, consiguiera la aprobación del ayuntamiento pues los datos que poseemos le sitúan renunciando su escribanía en Gonzalo García el 13 de marzo de $1515^{116}$. Otro caso de vacante por fallecimiento se produce tras la muerte del escribano Diego Sánchez, quedando la vacante resultante cubierta por Diego Pérez de Lequeito mediante concesión real de 16 de junio de $1537^{117}$.

Un supuesto de privación del oficio tendría que haberse producido en la persona de Cristóbal Arias, antecesor de Diego González. Efectivamente, según referimos anteriormente, la renuncia de Arias tuvo lugar estando ya encausado e, incluso como afirma algún testigo, probado el delito de falsedad antes de dar ocasión a ser condenado por sentencia judicial. Con la venta y renuncia del oficio a Diego González Arias eludió la pertinente sanción, esto es la privación del oficio, pena en que incurrían los condenados por falsarios ${ }^{118}$.

El acrecentamiento es otra vía de acceso que consiste en la creación de un oficio que, en nuestro caso, hace la Corona por encima del número cierto. Inicialmente fijado con la intención de amortiguar la tensión entre el poder real y el comunal en torno al derecho de creación de notarios, era un número que, normalmente, no se podía sobrepasar ${ }^{119}$. Con el fin de reducir la exorbitante cifra de escribanías de número generada durante los reinados de Juan II y Enrique IV, los Reyes Católicos implantaron el sistema de amortización, una vez vacantes, de los oficios excedentes $^{120}$. Sin embargo, en la práctica, aunque de forma más mesurada, el aumento de oficios continuó, unas veces, a petición de los concejos y, otras, por iniciativa de los propios monarcas ${ }^{121}$. Obviamente, en Cádiz el incremento de escribanías, de tres a seis y después a siete, fue consecuencia del recurso a este mecanismo pero desconocemos cuándo se acrecentaron tales oficios y quiénes fueron sus iniciales adquirentes.

Al respecto, una de las causas esgrimidas por las autoridades para negar a Diego González el acceso al cargo que pretende es que se trata de un oficio acrecentado a su anterior titular y, como tal, debía ser consumido tanto más cuanto los escribanos existentes apenas si pueden mantenerse, habida cuenta del reducido

114. Bono Huerta 1990, p. 25.

115. Apéndice, doc $n^{\circ} 1$.

116. Anexo.

117. Anexo. Por su parte, la escribanía del concejo que también servía Diego Sánchez la ocupó a su muerte Pedro Álvarez, por concesión real de 16 de junio de 1537, tomando posesión de ella, a través de representante, el 29 de octubre del mismo año, AGS, CCA, 238, 94, 5-6.

118. Cfr. supra requisito de idoneidad moral.

119. Bono Huerta 1982, vol. I-2, p. 143.

120. Ibid., p. 294.

121. Ostos Salcedo 1995, pp. 178-180; Arroyal Espigares, Cruces Blanco, Martín Palma 1991, pp. 26-33, Rojas García 2015, pp. 25-27. 
término y la escasa población de la localidad ${ }^{122}$. Los testigos de la ciudad coinciden tanto en la certeza del acrecentamiento, pues nunca antes de tres o quatro años a esta parte han visto usar y residir el oficio ${ }^{123}$, cuanto en que seis escribanías es una cifra excesiva para esta çibdad que es pequeña y bastan para çibdad mucho mayor que ésta así como que nunca solía aver en esta dicha çibdad sino tres escriuanos públicos ${ }^{124}$ :

...dixo que el tienpo de este testigo se acuerda que a los dichos çinqüenta años nunca vido vsar ni exercer el dicho ofiçio que el dicho Christóval Arias tenía, salvo al dicho Christóval Arias, de tres o quatro años a esta parte. Pero que de antes nunca se vsó ni exerçitó ni sabe de dónde ni cómo ovo el dicho Christóval Arias la dicha escriuanía (Antón Machorro, Prob 1, preg 5).

...dixo que según es la çibdad pequeña bastan los seys escriuanos públicos del número que agora en ella ay e aún bastarian para otra çibdad mayor (Antón Machorro, Prob 1, preg 6).

De estas alegaciones González se defiende indicando que aunque fuera un oficio acrecentado, dado que Cristóbal Arias fue recibido, él no puede ser excluido, en especial no tratándose de un caso de vacante por muerte. A tal fin aporta el testimonio de toma de posesión de su antecesor donde consta que Cristóbal Arias, vecino de Sevilla, accedió al cargo previa renuncia de Rodrigo de Arenas ${ }^{125}$.

Por otro lado, resulta llamativa la opinión de Fernán Sánchez, escribano público, uno de los testigos interrogados, quien cree que está acreçentado el dicho Christóval Arias e con favor de Juan de Haya fue reçebido porque le dixeron a este testigo que lo avía prometido a Covos, criado de Conchillos ${ }^{126}$. De ser cierto, y si se hizo efectiva la cesión a Cobos, la consecuencia inmediata pudo haber sido o, bien, la venta o, bien, el arrendamiento del oficio $\mathrm{y}$, en este último caso, la separación entre la propiedad del oficio y su ejercicio, usual desde tiempos de los Trastámaras $^{127}$ y legalmente prohibida ${ }^{128}$. Concierne aquí a Francisco de los Cobos, entonces criado del secretario de la reina, Lope de Conchillos y Quintana ${ }^{129}$. En cualquier caso, esta circunstancia encaja a la perfección con otros ejemplos que, aunque de época anterior, muestran la concesión por parte de la Monarquía de oficios de escribanía a cortesanos que ni residían ni iban a morar en el lugar donde estaba incardinado el oficio en cuestión ${ }^{130}$ y que deriva, mayoritariamente, en el ejercicio del oficio mediante sustituto o lugarteniente ${ }^{131}$.

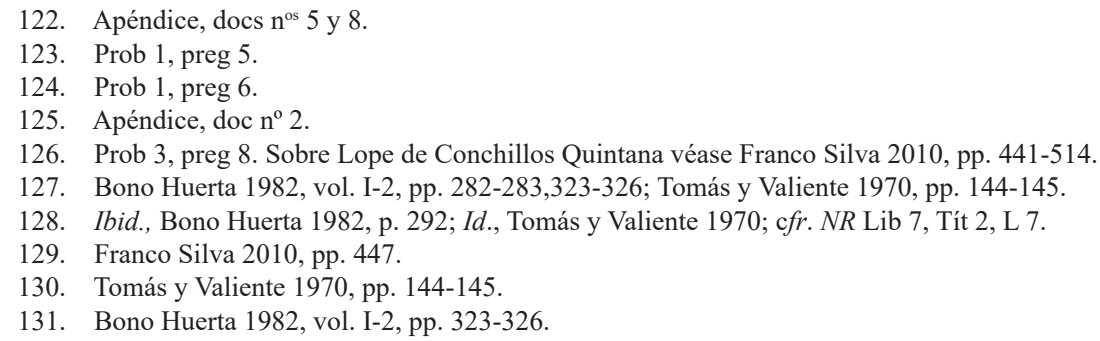


La práctica de la sustitución se constata, pues, en Cádiz como en otros lugares de Castilla ${ }^{132}$. Sabemos que Pedro Galíndez, escribano público de Cádiz, según Juan de Amar, su hijo, ejerció el oficio él u otro por él ${ }^{133}$, en clara alusión a la lugartenencia, situación ésta que ratifica el testigo de la ciudad Cristóbal Gentil al indicar que el escribano Fernando Suárez sirvió la escribanía del padre de Amar ${ }^{134}$. Al respecto de Amar, es probable que, una vez recibido en cabildo y mientras alcanzaba la mayoría de edad, el uso de la escribanía se encomendara a un lugarteniente ${ }^{135}$.

Otro ejemplo de sustitución, aunque relativo a una escribanía del concejo ${ }^{136}$, es el de Pedro Álvarez de Pavía, hombre de cámara de la emperatriz Isabel, hijo de Isabel Hernández de Magallanes, ama y camarera de la reina ${ }^{137}$. Álvarez, por concesión real de 16 de junio de 1537, era nombrado escribano municipal, cubriendo la vacante ocasionada con la muerte de Diego Sánchez, su anterior titular ${ }^{138}$. El 2 de noviembre de 1537 tomaba posesión y, a tal efecto, comparecía ante el cabildo representado por el escribano de número Manuel Ferraz, siendo recibido por las autoridades gaditanas con condición de que acudiera a Cádiz a usar personalmente el oficio como mandaba el rey. Ferraz, su representante, pedía testimonio del recibimiento syn perjuizio del aditamento que sus merçedes ponen para quel dicho su parte, por sý o por otra persona, pueda vsar el dicho ofiçio, según mandato real $^{139}$, interpretando muy ampliamente, en beneficio de su representado, la condición limitativa impuesta por el ayuntamiento. Como en el caso de Francisco de los Cobos, resulta difícil creer que Álvarez se desplazara a Cádiz desde la Corte expresamente para servir por sí la escribanía. De hecho, el 16 de mayo de 1538 renunciaba el oficio en Manuel Ferraz ${ }^{140}$, habiendo transcurrido tan solo nueve meses desde la concesión real y siete escasos desde la toma de posesión. En fin, no son muchos los ejemplos pero sí son suficientes para mostrar un modo de hacer cuyo uso implicaba, de ordinario, el arrendamiento del oficio al sustituto por precio y a tiempo limitado y, por ende, el incremento de los honorarios para compensar la renta debida al titular con el consiguiente perjuicio de los administrados ${ }^{141}$.

132. Veánse para Jerez de la Frontera, Rojas Vaca 1995, pp. 305-308; para Málaga Arroyal Espigares, Martín Palma, Cruces Blanco 1995, 69-70; para Córdoba, Ostos Salcedo 1995, pp. 185-186. En Sevilla, en lo atinente a escribanos de número, no se constata esta práctica aún cuando se sospecha, Pardo Rodríguez 1994, p.163; 1995, p. 277.

133. Apéndice, doc $n^{\circ} 1$.

134. Prob 1, preg 4.

135. Habiendo servido Fernando Suárez la escribanía del padre, pudo también servir la del hijo, id.

136. En Sevilla, dentro del ámbito de la escribanía del concejo, era habitual la lugartenencia, Pardo Rodríguez 1994, p.163-164; 1995, p. 277. También en Jerez de la Frontera constatamos esta práctica para el mismo ámbito, Rojas Vaca 2010, pp. 291-293.

137. Labrador Arroyo 2000, $1^{\text {a }}$. Parte, vol. II-3, p. 96.

138. AGS, CCA, 238, 94, 5 .

139. Ibid., 6 .

140. Ibid., 1-4

141. Tomás y Valiente 1970, p. 145; Bono Huerta 1982, vol. I-2, pp. 282-283. 


\subsection{Documentación}

Pergeñada la institución, abordamos la actividad documental que el notario desarrolla en el ejercicio estricto de su función cual es, con preferencia, la de autorizar las actuaciones y hechos otorgados por los particulares.

Al analizar la praxis documental, en ausencia de protocolos notariales de Cádiz coetáneos al pleito, nos apoyamos en dos registros fragmentarios de 1531, 1538-1539, los más antiguos que se conservan anteriores a $1550^{142}$. Igualmente, nos servimos de dos juicios de residencia de 1532 y 1535, pregonados en la plaza de la Corredera ante el poyo-avditorio, el primero, y en la puerta de la abdiençia, baxo de las casas del cabildo, en haz de mucha gente, el otro. Estas residencias no se dirigen específicamente al colectivo notarial, pues evalúan, en especial, la gestión de los corregidores salientes, a saber, el capitán Nicolás de Artreta en $1532^{143}$ y Francisco Cherino en $1535^{144}$. No obstante, al extenderse a los oficiales bajo su cargo, nos informan con carácter general de la actuación de nuestros escribanos.

Los datos que ofrecen las residencias son muy limitados en consonancia con el tipo de juicio practicado y proceden de la visión de los testigos interrogados en la pesquisa secreta, diecinueve en un caso ${ }^{145}$ y quince en otro ${ }^{146}$. Asimismo, están condicionados por las preguntas planteadas, iguales en número y contenido para ambos años:

142. Son 6 los protocolos de Cádiz que se conservan anteriores a 1550. Véase Carmona de los Santos, Parera Fernández-Pacheco 1977. Los dos protocolos más antiguos, fragmentos en realidad, son del escribano público Alonso de Medina, hermano de Diego González, el notario encausado en 1514, y corresponden a los años 1531 (AHPC, PN, oficio 24, 5.463) y 1538-1539 (AHPC, PN, oficio 24, 5.464).

143. AGS, CRC, 255, 1 .

144. AGS, CRC, 246, 3 .

145. Los testigos interrogados en 1532 son: Alonso Galíndez de Mar, vecino de Cádiz (35 años), Bachiller Antón de Frías, abogado en Cádiz (32), Esteban Gentil, regidor de Cádiz (60), Benito Martínez, abogado de Cádiz (40), Pedro Sánchez Estopiñán, regidor, vecino de Cádiz (29), Fernando de Cubas, regidor, vecino de Cádiz (40), Lope de Medina, escribano público (45), Alonso de Medina, escribano público (38), Comendador Pedro de Benavente, veinticuatro de Jerez (28), Cristóbal Rafael Italián, vecino de Cádiz (45), Pedro Lorenzo, escribano del rey y procurador (28), Damián Morel, mercader catalán (40), Lorenzo García, mercader, vecino de Cádiz (60), Jaime Fi de Jaime, Juana Vázquez, estante en Cádiz, Cristóbal de Vega, procurador, vecino de Cádiz (43), Marco Lomelín, mercader genovés, estante en Cádiz (30), Juan Osuche, mercader de Lucca, estante en Cádiz (30) y Diego Castaño, corredor de lonja, vecino de Cádiz (60).

146. Los testigos interrogados en 1535 son: Diego Ramírez de la Rúa, escribano público (45 años), Diego Sánchez de Argumedo, regidor, vecino de Cádiz (44), Pedro Cabrón, regidor, vecino de Cádiz (27), Cristóbal Rafael Italián, mayordomo (48), Francisco Calar, procurador (38), Damián Morel, mercader catalán, vecino de Cádiz (40), Gabriel Embeja, vecino de Cádiz (43), Diego de Padilla, escribano del rey y procurador (26), Fernán Gutiérrez, procurador, vecino de Cádiz (43), Luis Vivián, escribano público (28), Cristóbal Camacho, vecino de Cádiz (35), Diego Castaño, corredor de lonja, vecino de Cádiz (más de 65), Jaime de Ralfas (35), Luis de Salamanca, mercader burgalés, estante en Cádiz (28), Francisco de los Cameros, notario apostólico y del consistorius de Cádiz. 
1. Primeramente, si conosçen a los escriuanos públicos que son en esta çibdad.

2. Yten si saben que los dichos escriuanos ayan vsado bien sus ofiçios continuando las avdiençias e sy van, siendo llamados, para fazer los contratos e avtos que requiere a sus ofiçios.

3. Yten si saben que ayan llevado derechos demasiados de los contenidos en el aranzel desta çibdad e derechos que no pudiesen llevar.

4. Yten si saben que ayan fecho alguna falsedad en sus ofiçios de cuya cavsa se aya seguido daño a las partes.

5. Yten si saben que los dichos escriuanos ayan fecho los proçesos que ante ellos pasan en hoja de pliego entero e las escripturas que ante ellos pasan si las tienen bien guardadas para dar cuenta de ellas a sus dueños e si por buscar a las partes llevan o an llevado algunos derechos.

6. Yten si saben que los dichos escriuanos ayan llevado algunos derechos de los proçesos que pasan ante ellos pertenesçientes al conzejo de la dicha çibdad de la parte de la dicha çibdad.

7. Yten si saben que los dichos escriuanos ayan llevado algunos cohechos o dádivas de las partes que ante ellos truxesen pleyto e si por amor o amistad han dethenido las escripturas de no las dar a sus dueños e fecho alguna cosa que no deban en sus ofiçios ${ }^{147}$.

De ambas residencias los escribanos no salen mal parados. Los testigos estiman que usan bien sus oficios y que acuden a hacer los contratos y autos cuando les llaman ${ }^{148}$.

Sólo excepcionalmente se alude al cobro excesivo de derechos por encima del arancel establecido ${ }^{149}$, circunstancia ésta que algún testigo expresamente niega porque a todos los tiene por personas de conçiençia e que no les a visto llevar derechos demasiados ${ }^{150}$ mientras, por contra, otro entiende que son pocos los escribanos que lo guardan por cuanto los honorarios que perciben son escasos ${ }^{151}$. Salvo los que no saben, los más entienden que no han incurrido en falsedad alguna pues, si la oviesen fecho, no faltaría quien lo dixese $e^{152}$.

En general manifiestan que hacen las escrituras conforme a las Pragmáticas de estos reinos ${ }^{153}$, en registros de papel de pliego entero que tienen en cobro bueno e bien fechos ${ }^{154}$, guardando tanto las escrituras como los registros a buen recau$\mathrm{do}^{155}$. En lo judicial, cuando se pronuncian, estiman que hacen los procesos como

147. AGS, CRC, 255, 1, 17, f. XVr-v; AGS, CRC, 246, 3, s.f.

148. Según Esteban Gentil, regidor de Cádiz, y Cristóbal Rafael Italián, vecino de Cádiz. Dada la coincidencia de preguntas y respuestas, remitimos sólo a las afirmaciones vertidas por los testigos del juicio de 1532, el más antiguo.

149. Aparte del arancel general de los Reyes Católicos (NR Lib 4, Tít 27) no conocemos ningún arancel notarial específico para el Cádiz de la época. Los había en Sevilla, Córdoba y Jerez de la Frontera, véanse Bono, Ungueti 1986, p. 32; Pardo Rodríguez 1998, pp. 525-536; Ostos Salcedo 1995, p. 201; 1998, pp. 503-524; Rojas Vaca 1995, pp. 308-309.

150. Benito Martínez, abogado de Cádiz.

151. Fernando de Cubas, regidor, y Pedro Lorenzo, escribano del rey y procurador.

152. Pedro Lorenzo, escribano del rey y procurador.

153. Benito Martínez.

154. Bachiller Antón de Frías, abogado de Cádiz.

155. Benito Martínez. 
quieren a las vezes en pliego entero e con medio ${ }^{156} \mathrm{o}$, directamente, algunos dan petiçiones en medios pliegos de papel... y, en cualquier caso, quando se buscan algunas escripturas se les da alguna cosa de su trabajo ${ }^{157}$.

Entienden, asimismo, que no han llevado derechos en los procesos pertenecientes al concejo, sólo que la ciudad paga algún dinero a los escribientes por el trabajo que realizan ${ }^{158}$. En fin, todos declaran no saber si los escribanos han llevado cohechos o dádivas de las partes en los pleitos que pasan ante ellos ni, si por amor o amistad, han dethenido las escripturas para no darlas a sus dueños ni si hicieron en sus oficios alguna cosa indebida.

Por su parte, el examen de los protocolos seleccionados manifiesta cómo no era inusual que los notarios incumplieran las disposiciones de la Pragmática de Alcalá, dictada por Isabel I en 1503, marco legal que regula su quehacer documental durante el período que nos ocupa ${ }^{159}$. En especial esto es evidente en lo relativo al modo de asentar la matriz en el protocolo pues, mientras la ley marcaba la extensión íntegra en el registro, la práctica pone al descubierto la existencia de matrices con espacios blancos que, en el momento del otorgamiento, no fueron rellenados ${ }^{160}$. De este modo, se redacta en la matriz la sustancia de la escritura y, tras el blanco destinado a la fuerza o generalidad de aquélla, se consignan la data, la testificación y las suscripciones del otorgante u otorgantes y del notario. Se trata de un proceder que responde a una distribución del trabajo en el oficio entre varios con el fin de agilizarlo, una de cuyas consecuencias era que las partes otorgaban o consentían una escritura incompleta, sin terminar. Podríamos pensar también que algunas matrices, escritas en su totalidad pero realizadas por manos diferentes con arreglo a tal esquema, estuvieron preparadas de antemano, rellenándose los blancos en el momento del otorgamiento ${ }^{161} \mathrm{o}$, bien, que, siguiendo la pauta anterior, se hincharon o engrosaron tras ser otorgadas.

Este modo de hacer no fue excepcional. Antes al contrario, por la amplitud de su uso revela, también en la desviación de la norma, la uniformidad de la práctica andaluza y, por extensión, castellana ${ }^{162}$. Y puesto que de incumplir la ley se trata, cabe señalar cómo nuestro escribano no siempre salva los yerros ${ }^{163}$ aun cuando la presencia de interlineados, tachados y enmiendas no es escasa. Advertimos, asimismo, la ausencia de suscripción notarial en no pocos ejemplares, aunque su

156. Antón de Frías.

157. Pedro Lorenzo.

158. Fernando de Cubas, Pedro Lorenzo.

159. Libro de las Bulas y Pragmáticas de los Reyes Católicos 1973, T. II, ff. 361v-364r.

160. Por poner algún ejemplo se puede consultar AHPC, PN, oficio 24, 5.464, f. 851r, contrato de aprendizaje, y ff. 854v, 855r, 872rv, reconocimientos de deuda.

161. Bono Huerta 1990, p. 45.

162. Sobre el modo de asentar las matrices en el protocolo véanse Bono Huerta 1990, p. 45; Ostos Salcedo 1994, pp. 198-204; 1995, pp. 206-209; Moreno Trujillo 1995, pp. 90-93; Rojas Vaca 1995, pp. $312-313$; 1996, p. 65; 2005, pp. 76-77; Obra Sierra 2011, pp. 96-106; Obra Sierra, Moreno Trujillo 2012, pp. 352-368; Rojas García 2015, pp. 201-214; Crespo Muñoz 2007, pp. 189-191; Domínguez Guerrero 2016, pp. 312-362.

163. Libro de las Bulas y Pragmáticas de los Reyes Católicos 1973, T. II, f. 362v; cfr. NR Lib 4, Tít 25, L 13. 
aposición fuera obligada desde $1525^{164}$. Tampoco consigna al pie del asiento los derechos cobrados por la registración ${ }^{165}$, cuya reseña, por otro lado, no se generaliza entre los notarios gaditanos hasta la década de los ochenta del siglo XVI ${ }^{166}$.

En general, los fragmentos de protocolos analizados denotan bastante desaliño, resultado, en gran medida, de la casi total ausencia de márgenes y, consecuentemente, de la necesidad de tener que ajustar las diligencias a espacios, por lo reducido, inverosímiles. A este fin, nuestro notario usa no sólo los exiguos márgenes laterales de las hojas sino también los superiores e inferiores ${ }^{167} \mathrm{e}$, incluso, en ocasiones, los espacios comprendidos entre el final y el comienzo de dos escrituras consecutivas de forma que se solapan los contenidos ${ }^{168}$.

Por último, aunque los protocolos pertenecen a Alonso de Medina, es preciso señalar la presencia de matrices realizadas ante el notario Diego González, su hermano, quien, por otro lado, también interviene frecuentemente como testigo. En aquellas matrices figura reseñada su actuación en el ángulo superior izquierdo del asiento mediante la anotación ante Diego Gonçález, precedida de la indicación del negocio. En estos casos, la matriz va provista sólo de la rúbrica del notario en cuestión $^{169}$.

En suma, el notariado público gaditano a comienzos del siglo XVI, tanto en lo relativo a la institución como en lo atinente a la documentación, acusa características similares al andaluz y, por ende, al castellano. Las particularidades son escasas. En apretada síntesis y en lo que hace a la institución afectan, de un lado, al nombramiento de los notarios y, de otro, al requisito de vecindad.

En efecto, al respecto del nombramiento, resulta llamativa la casi total falta de intervención de la ciudad en el proceso previo a la nominación regia. Se constata a través de la elección del candidado, en caso de vacante tras fallecimiento, sólo cuando el sucesor es pariente, hijo, nieto o yerno, del notario fallecido, según privilegio real extensivo, igualmente, a las regidurías gaditanas. De otro lado y, como consecuencia del carácter regio de la nominación, es evidente el desdén que en Cádiz se detecta en la práctica por el requisito de vecindad y, en su caso, de naturaleza exigido al aspirante a notario, aun cuando tal requisito lo esgrimiera el ayuntamiento para negar a González la entrada en ejercicio. Una exigencia en modo alguno baladí por cuanto nadie mejor que un vecino o natural para conocer y autorizar los documentos y negocios relacionados con la demanda de la ciudad.

Por último cabe apuntar cómo nuestros notarios se adecúan o, en su caso, se desvían de la norma en los mismos aspectos y medida que sus colegas andaluces y castellanos. Así, es dable afirmar que la desviación de la ley es consecuencia de

164. Sobre la firma del notario en la matriz véase Rodríguez Adrados 1988, pp. 632-639.

165. Libro de las Bulas y Pragmáticas de los Reyes Católicos 1973, T. II, 363 rv; NR Lib 4, Tít 27.

166. Rojas Vaca 1996, pp. 29-30; 2005, pp. 73-74.

167. AHPC, PN, oficio 24, 5.464, f. 286r.

168. Ibid., 5.463, f. 67 r.

169. Ibid., 5.464, f. 373 r. 
la ignorancia o relajación, o de ambas, que en su interpretación y aplicación se practicaba en la Corona de Castilla, no siempre de manera eventual, al tiempo que muestra la laxitud o, mejor incluso, arbitrariedad con que "a veces" las autoridades locales y la propia Monarquía ordenaban su cumplimiento.

\section{APÉNDICE DOCUMENTAL}

1499, septiembre, 30. Granada.

Los Reyes Católicos mandan al bachiller Suero de Novoa, corregidor de Cádiz, que informe al Consejo Real de la razón por la cual Juan de Amar, vecino de Cádiz e hijo del escribano público Pedro Galíndez, difunto, no es aceptado, cumplida la mayoría de edad, como tal notario por la ciudad.

AGS, RGS, Leg. 149909, 138, s.f.

(Cruz)

Don ${ }^{170}$ Fernando e doña Ysabel, etçetera, a vos, el bachiller Suero de Novoa, nuestro corregidor de la çibdad de Cádiz. Salud e graçia.

Sepades que Juan de Amar, fijo de Pedro Galíndez, difunto, veçino desa dicha çibdad, nos fizo relaçión por su petiçión diziendo quel dicho su padre fue escriuano público en esa dicha çibdad muchos tienpos, vsando e exerçiendo el dicho ofiçio él u otro por él. E diz que al tienpo quel dicho su padre fallesçió los regidores e ofiçiales desa dicha çibdad, conpliendo los vsos e antigua costunbre desa dicha çibdad e preuillejos della confirmados por nos, diz que le resçibyeron en su cabildo, todos juntos a canpana tannida, al dicho ofiçio de escriuanía como a fijo mayor del dicho su padre. E diz que porque en aquella sazón él hera menor de hedad no podía por su persona exerçer el dicho ofiçio fasta agora que diz que es de hedad perfeta. E diz que agora vos, el dicho nuestro corregidor, ge lo aveís ynpedido e no le avéis dado lugar a quél pueda vsar el dicho ofiçio, en lo qual diz quél ha resçibydo mucho agravio e daño. // Por ende que nos suplicaba e pedía por merçed mandásemos veer la eleçión por donde él fue elegido e resçibydo al dicho ofiçio e, asý mismo, los preuillejos confyrmados por nos que esa dicha çibdad diz que tiene para que en los ofiçios de ${ }^{171}$ regidorías e escrivanías subçedan los fijos e nietos o yernos de los tales regidores e escriuanos e aquellos se le guardasen mandándosele dar nuestra carta para quél fuese resçibydo al dicho ofiçio e para que lo vse e exerçite o, como la nuestra merçed fuese. Lo qual etçétera.

Por que vos mandamos que, del día que con esta nuestra carta fuerdes requerido fasta veynte días, primeros siguientes, enbyéys ante nos al nuestro Consejo la cavsa e razón que ay para no aver resçibydo al dicho ofiçio al dicho Juan de Amar porque visto mandemos proueer sobre ello lo que fuere justiçia.

E non fagades ende al, etçetera.

Dada en Granada a XXX días del mes de setienbre de XCIX años.

170. En el margen superior izquierdo: Juan de Amar. En posición central, bajo la cruz: Para quel corregidor de Cádiz enbie razón por qué no resçibe a vn escriuano de la dicha çibdad al ofiçio de escriuania a que fue elegido. Bajo el resumen: Setyenbre de XCIX.

171. Tachado: los. 
Iohannes, episcopus ovetensis, Iohannes, liçençiatus, Martinus dotor, liçençiatus Çapata. Yo, Fernandus Tello, liçençiatus. Yo Castañeda, etçetera.

Bachalarius Alfonsus de Herrera (rúbrica).

1511, junio, 21. Cádiz.

Fernando Gascón, escribano del concejo de Cádiz, da fe de la recepción por el cabildo gaditano de Cristóbal Arias como escribano público del número de Cádiz, por renuncia de Rodrigo de Arenas.

AGS, CRC, 24, 7, $\mathrm{Cuad}^{0}$ 1, f. 33r.

(Cruz)

$\mathrm{A}^{172}$ todos quantos esta carta de fe vierdes que Dios honrre e guarde de mal.

Yo, Fernand Gascón, escriuano público y del cabildo de la noble çibdad de Cádiz por la reina nuestra señora, me vos encomiendo y vos hago saber y doy fe que en la dicha çibdad de Cádiz, sábado, veynte e vn días del mes de junio deste año que estamos de mill e quinientos e onze años, estando ayuntados en cabildo los nobles señores justiçia e regidores de la dicha çibdad por su alteza, vino al dicho cabildo Christóval Arias, veçino de Seuilla, y presentó vna carta de su alteza, firmada del rey nuestro señor, e librada de los del su muy alto Consejo, por la qual en efeto les mandava a los dichos justiçia e regidores que lo ovyesen y reçibiesen por escriuano público desta dicha çibdad por renusçiaçión que en él fizo Rodrygo de Arenas, según más largo en la dicha carta de su alteza se contiene, la qual por los dichos señores justiçia e regidores fue obedeçida e cunplida con el acatamiento que devían e ovyeron e reçibieron al dicho Christóval Arias por escriuano público desta dicha çibdad, del qual reçibieron el juramento e solemnidad que en tal caso se requería. Todo lo qual más largamente está escripto e asentado en mi libro registro al qual me refyero.

Y la dicha carta de su alteza quedó en mi poder, de lo qual yo, el dicho escriuano público, di esta fe al dicho Christóval Arias porque me la pidió, firmada de mi nonbre, e signada con mío signo, la qual le di en el dicho día, sábado, veynte e vno de junio de mill e quinientos e onze años.

Testigos que fueron presentes: Diego Sánchez, escriuano de su alteza, e el dicho Rodrigo de Arenas.

Yo, Fernand Gascón, escriuano público e del cabildo de la noble çibdad de Cádiz, lo fiz escreuyr e fiz aquí mío sig(signo)no e so testigo (rúbrica) $)^{173}$.

1514, septiembre, 25. Valladolid.

Juana I, reina de Castilla, concede a Diego González, escribano, vecino de Cádiz, un oficio de escribano público del número de Cádiz por renuncia de Cristóbal Arias, su anterior titular.

B.- AGS, CRC, 24, 7, Cuad $^{0}$ 1, ff. 2r-3v.

172. Sobre el documento: fe de cómo Christóual Arias, renunçiante, tomó la posesión del ofiçio por renunçiaçión de Rodrigo de Arenas.

173. Presentada ante el Consejo Real en 13 de junio de 1515. 
Doña ${ }^{174}$ Juana, por la graçia de Dios, reina de Castilla, de León, de Granada, de Toledo, de Galizya, de Seuilla, de Córdova, de Murçia, de Jahén, de los Algarves, de Algezyra, de Gybraltar e de las yslas de Canaria e de las yslas Yndias e tierra firme del mar oçéano, prinçesa de Aragón e de las dos Seçilias, de Iherusalén, archiduquesa de Avstrya, duquesa de Borgoña y de Bravante, condesa de Flandes e de Tyrol, señora de Vizcaya e de Molina, etçétera, por fazer bien e merçed a vos, Diego Gonçález, mi escriuano, vezyno de la çibdad de Cádiz, acatando vuestra sufiçiençia e //2v. abilidad e los seruiçios que me avéys fecho, es mi merçed e voluntad que, agora e de aquí adelante para en toda vuestra vida, seáys mi escriuano público del número de la dicha çibdad de Cádiz en lugar e por renunçiaçión de Christóval Arias, mi escriuano del número que fue de la dicha çibdad, por quanto asý me lo suplicó e pidió por merçed por vna su petyzión e renunçiaçión, synada de escriuano público, que ante algunos del mi Consejo fue presentada.

E por esta mi carta mando al conçejo, justiçia, regidores, caualleros, escuderos, ofiçiales e ommes buenos de la dicha çibdad de Cádiz que, luego que con ella fueren requeridos syn esperar para ello otra mi carta ni mandamiento ni segunda ni terçera jusyón, juntos en su cabildo e ayuntamiento, según que lo han de vso e de costunbre, tomen e reçiban de vos, el dicho Diego Gonçález, el juramento e solenidad que en tal caso se requiere e devéys fazer. El qual asý fecho vos ayan e reçiban e tengan por mi escriuano del número de la dicha çibdad de Cádiz, en lugar del dicho Christóval Arias, e vsen con vos en el dicho ofiçio y en todos las cosas e casos a él anexas e conçernientes e vos guarden e fagan guardar todas las honrras, graçias, merçedes, franquezas e libertades, esençiones, preminençias, prerogativas e ynmunidades que por razón del dicho ofiçio devéys aver e gozar e vos deven ser guardadas e vos recudan e fagan recudir con todos los derechos e salarios e otras cosas al dicho ofiçio anexas e perteneçientes, sý e segúnd que se ha vsado, guardado e recodido, asý al dicho Christóval Arias como a cada vno de los otros mis escriuanos que han seydo e son de la dicha çibdad. //3r. De todo bien e conplidamente en guisa que vos non mengüe ende cosa alguna que yo, por la presente, vos reçibo e he por reçebido al dicho ofiçio e al vso y exerçiçio dél. E vos doy poder e facultad para lo vsar y exerçer caso que por los susodichos o por alguno de ellos a él no seáys reçebido.

La qual dicha merçed vos fago con tanto que el dicho Christóval Arias biva después de la fecha desta mi carta los veynte días que la ley dispone e con que os ayáis de presentar e presentéys con esta mi carta en la casa del cabildo e ayuntamiento de la dicha çibdad dentro de sesenta días primeros syguientes que se cuente desde el día de la fecha de ella en adelante. Y que sy asý no lo fizierdes ayáis perdido e perdáys el dicho ofiçio e quede vaco para yo poder hazer merçed dél a quíen mi voluntad fuere. E con que al presente no seáys de corona y sý en algúnd tyenpo pareçiere que lo soys ansý mismo hayáis perdido e perdáis el dicho ofiçio.

E con que tome la razón desta mi carta Françisco de los Covos. Y es mi merçed e mando que, todas las escripturas e otros autos que ante vos pasaren e se otorgaren en la dicha çibdad de Cádiz y en su tierra, valgan y fagan fe ansý en juizyo como fuera dél como cartas e escripturas fechas e otorgadas ante mi escriuano del número de la dicha çibdad.

E los vnos nin los otros non fagades nin fagan ende al por alguna manera so pena de la mi merçed e de diez mil maravedíes para la mi cámara a cada vno ${ }^{175}$ que lo contrario fizyere.

Dada en la villa de Valladolid a XXV días del mes de setienbre año del nasçimiento de Nuestro Señor Ihesuchristo de mill e quinientos e catorze años.//3v.

Yo, el rey (rúbrica).

174. Al margen izquierdo: la prouissión del ofiçio a Diego Gonçález.

175. Al margen izquierdo: Dada. 
Yo, Lope Conchillos, secretario de la reyna nuestra señora, la fize escreuir por mandado del rey, su padre.

E en las espaldas de la dicha carta de su alteza estavan escriptos las fyrmas e nonbres syguientes: liçençiatus Zapata, doctor Caravajal. Registrada liçençiatus Ximénez. Castañeda, chançiller.

1514, octubre, 19. Valladolid.

Juana I, reina de Castilla, concede a Diego González una escribanía de los reinos.

AGS, CRC, 24, 7, Cuad $^{0}$ 1, f. 31r-v.

(Cruz)

Doña ${ }^{176}$ Juana, etçétera, por fazer bien e merçed a vos, Diego Gonçález, vezyno de la çibdad de Cádiz, acatando vuestra sufiçiençia e abilidad, tengo por bien y es mi merçed e voluntad que, agora e de aquí adelante para en toda vuestra vida, seáys mi escriuano e notario público en la mi Corte y en todos los mis reinos e señoríos.

E por esta mi carta, o por su traslado synado de escriuano público, mando al Ilustrísimo prínçipe don Carlos, mi muy caro e muy amado hijo, e a los infantes, duques, condes, perlados, ricos hombres, maestres de las órdenes, priores, comendadores, subcomendadores, alcaldes de los castillos e casas fuertes e llanas e a los del mi Consejo e oídores de las mis abdiençias, alcaldes, alguaçiles de la mi casa y corte e chançillerías y a todos los conçejos, corregidores, asistentes, alcaldes, alguaçiles, merinos, prebostes, regidores, jurados, caualleros, escuderos, ofiçiales e ommes buenos de todas las çibdades, villas e lugares de los mis reinos e señoríos, asý a los que agora son como a los que serán de aquí adelante, que vos ayan e tengan e reçiban por mi escriuano e notario público de la dicha mi corte e de los dichos mis reinos e señoríos e vsen con vos en el dicho ofiçio e vos recudan e fagan recudir con todos los derechos, salarios al dicho ofiçio anexos e pertenesçientes, según que recudieron e fizieron recudir y es recudido a cada vno de los otros mis escriuanos e notarios públicos de la dicha mi corte, de los dichos mis reynos e señoríos. De todo bien e cunplidamente en guisa que vos non mengüe ende cosa alguna e que vos guarden e fagan guardar todas las onrras, graçias, merçedes, $<$ franquezas $>177$ e libertades, esençiones, prerrogativas, ynmunidades e todas las otras cosas e cada vna de ellas que se suelen e acostunbran guardar a cada vno de los otros mis escriuanos e notarios públicos de la dicha mi corte e los dichos mis reinos e señoríos. E que en ello ni en parte de ello enbargo ni contradiçión vos no pongan ni consientan poner, ca yo por la presente vos reçibo y he por reçebido al dicho ofiçio e al vso y exerçiçio dél. E vos doy poder e facultad para lo vsar y exerçer.

$\mathrm{Y}$ es mi merçed e mando que todas las cartas y escrituras, ventas e poderes y obligaçiones e testamentos e codiçilos e otras cualesquier escrituras $/ /^{31 v}$ e abtos judiçiales y estrajudiçiales que ante vos, el dicho Diego Gonçález, pasaren e se otorgaren a que fuéredes presente en que fuere puesto el día y el mes e año e lugar donde se otorgaren e los testigos que a ello fueren presentes e nuestro signo a tal como éste (signo) que yo vos doy, de que es mi merçed e mando que vsedes, que valga e faga fee, asý en juizio como fuera dél, como cartas y escrituras firmadas e synadas de mano de mi escriuano e notario público de la

176. En el ángulo superior derecho: El título de Diego Gonçález de escriuano del reyno.

177. Entre renglones. 
dicha mi Corte e de los dichos mis reinos e señoríos pueden e deven valer de derecho. E por evitar los perjuros, fravdes e costas e daños que de los contrabtos fechos con juramento $<$ e de las sumisiones que se haçen cautelosamente se siguen mando que no synéys contrato con juramento $>^{178}$ ni en que se obligue a buena fee syn mal engaño ni por donde lego alguno se someta a la jurisdiçión eclesiástica, so pena que si lo synardes por el mismo fecho ayáis perdido e perdáis el dicho ofiçio de escriuanía. Otrosý con tanto que al presente no seáys clérigo de corona e si lo sois o fuéredes de aquí adelante en algún tienpo que luego por el mismo fecho ayáis perdido e perdáis el dicho ofiçio de escriuano e no seáys más mi escriuano ni vseys del dicho ofiçio, so pena que si lo vsardes dende en adelante seáys avido por falsario sin otra sentençia ni declaraçión alguna.

E los vnos nin los otros non fagades ni fagan ende al etcétera, pena diez mill.

Dada en la villa de Valladolid a diez e nueve días del mes de otubre, año del nasçimiento de nuestro Salvador Ihesuchristo de mill e quinientos e catorze años.

Yo, el rey.

Yo, Lope Conchillos, secretario de la reina, nuestra señora, la fize escreuyr por mandado del rey, su padre.

$\mathrm{Y}$ en las espaldas de la dicha carta estavan los nonbres siguientes: archiepiscopus granatensis. Doctor Carabajal. Liçençiatus Polanco. Françiscus liçençiatus. Liçençiatus de Sosa. Doctor Cabrero.

Y ençima de la firma del dicho doctor Cabrero 179 dezía: "ábil es".

Registrada liçençiatus Ximénez. Castañeda, chançiller. Obligose. Dio ynformaçión en forma.

Va entre renglones e diz "franquezas" e ó diz "e de las sumisiones que se haçen cabtelosamente se siguen mando que no synéys contrabto con juramento". Va testado do dezía "donde".

Liçençiatus Ximénez (rúbrica).

1514, noviembre, 9-11. Cádiz ${ }^{180}$.

Diego González requiere a Alonso Sánchez de la Vera, teniente del corregidor de Cádiz Pedro de Bazán, para que no contradiga su recepción como notario de la ciudad. El teniente responde que suspende ésta hasta que el pleito se resuelva e inserta las razones de la suplicación de la ciudad.

AGS, CRC, 24, 7, $\mathrm{Cuad}^{\circ}$ 1, ff. 17r-18r.

$(\mathrm{Cruz})$

$E n^{181}$ la noble çibdad de Cádiz, nueve días del mes de novienbre año del naçimiento de nuestro Salvador Ihesuchristo de mill e quinientos e catorze años.

178. Entre renglones.

179. Tachado: donde.

180. Fue presentado ante el Consejo Real el 6 de diciembre de 1514

181. Sobre la cabecera del documento: Vn testimonio que tomó Diego Gonçález contra el teniente de Cádiz que le dexase vsar del ofiçio y lo que respondió el teniente y en la respuesta inserta la suplicaçión del ayuntamiento. 
Ante el virtuoso señor bachiller Alonso Sánchez de la Vera, teniente de corregidor desta dicha çibdad por el noble cauallero el señor Pedro de Baçán, corregidor e justiçia mayor de ella por la reyna nuestra señora, e en presençia de mí, el escriuano público, e de los testigos de yuso escritos, estando en abdiençia, paresçió presente Diego Gonçález, vezino desta dicha çibdad, e dio e presentó a mí, el dicho escriuano público, vn escrito de razones el qual pidió leyese al dicho señor teniente, su tenor del qual dicho escrito es este que se sygue:

Françisco de Mayorga, escriuano público del número desta çibdad, dad por testimonio en manera que faga fee a mí, Diego Gonçález, escriuano público del número desta çibdad, cómo me asyento en este poyo con el señor teniente a dar fee de todos los abtos judiçiales e estrajudiçiales que ante mí pasaren, conforme a la carta real de su alteza, e le pido e requiero que no me lo contradiga, antes me aya por reçebido al dicho ofiçio pues que su alteza asý ge lo enbía a mandar. E me da poder e facultad para ello con protestaçión que hago que sy asý lo fizyere hará bien e derecho e lo que su alteza por la dicha su carta le enbía a mandar, donde no protesto de me querellar dél ante su alteza e ante quien con derecho deva, como de juez que no cunple las cartas e mandamientos de su alteza. E demás de cobrar dél e de sus bienes todos los daños e costas e yntereses que se me recreçieren e a los presentes ruego que de ello me sean testigos.

$\mathrm{E}^{182}$ asý presentado el dicho escrito por el dicho Diego Gonçález e leýdo por mí, el dicho escriuano público, el dicho señor teniente dixo que el dicho Diego Gonçález presentó en el cabildo desta çibdad una prouisyón de la reina nuestra señora de la qual por su parte e por parte del cabildo desta çibdad está suplicado por cabsas justas por donde el dicho Diego Gonçález no deve ser reçebido. Por ende que él suspendía el efeto della para que el dicho Diego Gonçález no se asyente ni vse del dicho ofiçio fasta que por su alteza sería determynada la dicha cabsa e vistas las cabsas de la suplicaçión. E que esto da por su respuesta, no consintiendo en sus protestaçiones ni en alguna dellas. E mandó enxerir en este testimonio las cabsas de la suplicaçión, las quales mandó a Diego Sánchez, escriuano público, que presente hera e teniente de escriuano de cabildo, que las diese a mí, el dicho escriuano público, firmadas de su nonbre, para //17v. las poner en este testimonio. E a mí, el dicho escriuano público, mandó que no se dé el dicho testimonio syn las dichas cabsas de suplicaçión en él ensertas.

El dicho Diego Sánchez, escriuano público, dixo que es presto de las dar.

El dicho Diego Gonçález lo pidió por testimonio.

Testigos: Lope de Medina e Diego Ramírez, escriuanos públicos, y Pedro de Zayas, alguaçil mayor, e Diego Fernández e Christóval de Vega, procuradores desta çibdad.

Después de lo susodicho, onze días del dicho mes de novienbre, año susodicho, el dicho Diego Sánchez, escriuano público, dio a mí, el dicho escriuano público de yuso escrito, vna escritura de capítulos, firmada de su nonbre, que dixo que hera la que el dicho señor teniente le avía mandado que me diese para poner encorporada en el dicho testimonio, su tenor de la qual es este que se sygue:

- Lo primero porque el dicho ofiçio fue conprado públicamente por lo que es perdido e no puede vsar dél conforme a las leyes e premáticas de estos reynos.

- Lo otro porque es contra los vsos e buenas costunbres e cartas e provisyones de su alteza que esta çibdad tiene por las quales confirma a los ofiçios de regimientos e

182. Al margen: respuesta. 
escriuanías en los veçinos e fijos de veçinos e naturales desta dicha çibdad. E no lo syendo el dicho Diego Gonçález no puede ser al dicho ofiçio de escriuanía reçebido.

- Lo otro porque es en oprobio e menospreçio desta dicha çibdad porque seyendo como es esta çibdad tan noble e tan antigua e aviendo sydo en ella syenpre los dichos escriuanos públicos de los más honrrados e prençipales de ella, concurriendo de todas del mundo a esta çibdad sería gran vituperio e menospreçio el dicho Diego Gonçález ser escriuano público de ella siendo como es christiano nuevo, onbre de baxa condiçión e prove e de poca abtoridad, seyendo el dicho ofiçio de tanta filedidad ${ }^{183}$ que no se deva dar saluo a personas que por cosa del mundo no se pueda presumir que en él haga cosa que no deva.

- Lo otro porque la cabsa que a Christóval Arias movió a renunçiar el dicho ofiçio al dicho Diego Gonçález fue porque el dicho Christóval Arias fizo un codeçillo de vna Elvira Estopiñán, la qual avía vn año hablava ${ }^{184}$ por razón de çierta enfermedad que tenía de que murió e en las palabras del dicho codeçilio el dicho Christóual Arias dio fee que estava en su seso e que por su propia boca lo avía fecho estando ella//18r. que no hablava, como dicho es, e porque sobre el dicho codeçilio andavan en pleyto estava provado la dicha Eluira Estopiñán no hablar a esta cabsa este yerro que el dicho Christóual Arias avía fecho conosçiendo thener perdido el dicho ofiçio lo renunçió en el dicho Diego Gonçález, el qual dicho Diego Gonçález fue testigo del dicho codeçillio e escrivió por donde se presume que fue partíçipe en el dicho yerro con el dicho Christóual Arias.

- Lo otro porque el dicho Diego Gonçález es clérigo de corona, la qual a traýdo abierta e seyéndolo tiene perdido el dicho ofiçio e si lo vsase tiene las penas contenidas en las leyes e premáticas de su alteza.

- Lo otro porque el dicho ofiçio es acreçentado, que antiguamente no solía aver saluo tres escriuanos públicos en esta çibdad e agora ay siete a cabsa de ser esta çibdad tan pequeña no se pueden sostener ni mantener los dichos escriuanos públicos. Diego Sánchez (rúbrica).

De todo lo qual, según dicho es, yo, el dicho escriuano público de yuso escripto, di ende éste al dicho Diego Gonçález.

Que es fecho en la dicha çibdad de Cádiz los dichos días, mes y año susodicho del Señor de mill e quinientos e catorze años.

Yo, Françisco de Mayorga, escriuano de la reyna nuestra señora e su notario público e escriuano público del número de la dicha çibdad de Cádiz, presente fui a todo lo que dicho es e lo fize escriuir e fize aquí este mi sig(signo)no a tal en testimonio de verdad. Françisco de Mayorga (rúbrica).

183. Sic.

184. Sic por que no hablava. 
$[1514 \text {, diciembre, } 6]^{185}$.

Diego González, vecino de Cádiz, escribano real y público del número, pide a la reina que le dé sobrecarta para que la ciudad de Cádiz le apruebe como notario.

AGS, CRC, 24, 7, $\mathrm{Cuad}^{\circ}$ 1, f. 10r.

$(\mathrm{Cruz})$

Muy poderosa señora

Diego Gonçález, vezino de la çiudad de Cádiz, escriuano de vuestra alteza e escriuano público del número de la dicha çibdad, con el acatamiento que devo, beso las muy reales manos de vuestra alteza, a la qual vmildemente, suplico plega saber que, en el mes de setienbre pasado deste presente año de catorze, vuestra alteza me fizo merçed de vna escrivanía del número de la dicha çibdad de Cádiz, en lugar e por renunçiaçión de Christóval Arias, escriuano del número que fue de la dicha çibdad. E a su suplicaçión e sobre la dicha razón vuestra alteza me mandó dar provisyón e carta. Por la qual mandó al conçejo, justiçia e regidores de la dicha çibdad tomasen e reçibiesen de mí el juramento e las otras solenydades que de derecho en tal caso se requieren e me toviesen por vn escriuano del número de la dicha çibdad en lugar del dicho Christóval Arias e que vsase del dicho ofiçio e me acudiesen con todos los derechos al dicho ofiçio perteneçientes so çiertas penas, según que más largamente en la dicha prouisyón se contienen.

E asý es que yo me presenté en la dicha çibdad e en el cabildo della e presenté la dicha carta a los dichos justiçia e regidores e les requerí con ella la cunpliesen, como en ella se contiene, como vuestra alteza lo mandava. Los quales non lo an querido ny quyeren fazer syn thener razón alguna que a ello les mueva, saluo por enemistad que me tienen algunos dellos que persodieron a todos los otros para desobedeçer el real mandado de vuestra alteza fingendo escusaçiones fríbolas e cabsas falsas e dinas de mucho castigo, lo qual paresçe muy notoryamente ser enemistad capital e no deseo de seruir a vuestra alteza. E no contentos con esto yo, conforme a la dicha carta, tomé la posesyón de la dicha escrivanýa e me presenté en el lugar donde suelen los escriuanos estar en el abdiençia e començé a fazer abtos. E el bachiller de la Vera, tenyente de la dicha çibdad, juntamente con los escriuanos que ende estavan, me echaron por fuerça del dicho lugar muy ynjuriosamente, mandándomelo el dicho teniente e los dichos escriuanos poniéndolo por la obra frontándome, segúnd todo más largamente paresçerá por estos testimonios de que $<$ ante $>186$ vuestra alteza fago presentaçión.

Porque pido e suplico a vuestra real alteza mande proveerme de justiçia sobre la dicha razón, mandándome dar sobrecarta real de vuestra alteza para los dichos justiçia e regidores para que me den e anparen en la dicha posesyón de que fue despojado e no me perturben en ella ni en cosa alguna della so grandes e graves penas. E vuestra alteza mande castigar a los perturbadores de su provisyón real.

Para lo qual e en lo neçesario el ofiçio real de vuestra alteza ynploro e pido conplimiento de justiçia e las costas, etçétera ${ }^{187}$.

185. Al carecer de fecha la consulta, hemos reseñado la data de su presentación ante el Consejo Real.

186. Entre renglón.

187. En el reverso: Consulta. 
[1514, diciembre, 9$]^{188}$.

Diego González, escribano real y público del número de Cádiz, responde a la suplicación del procurador de la ciudad de Cádiz.

AGS, CRC, 24, 7, Cuad $^{\circ}$ 1, ff. 19r-v.

(Cruz)

Muy poderosa señora ${ }^{189}$.

Diego Gonçález, escriuano de vuestra alteza e del número de la çibdad de Cádiz, digo que de la carta que vuestra alteza me mandó dar, por la qual me hizo merçed de la escriuanía del número de la dicha çibdad que tenía Christóual Arias por su renunçiaçión no hauía ni ha lugar suplicaçión ni otro remedio alguno. La suplicaçión ynterpuesta por el teniente y regidores de la dicha çiudad no fue puesta en tienpo ny en forma ny por cabsas bastantes y en el seguimiento de la dicha suplicaçión no se hizieron las diligençias deuidas. El mandamiento dado por la dicha carta es pasado en cosa juzgada.

Por tal suplico a vuestra alteza lo mande pronusçiar o, a lo menos, las dichas causas de la suplicaçión no ser bastantes y me mande dar sobrecarta con pena para el dicho teniente y regidores, lo qual se deue ansý mandar hazer syn enbargo de las razones contenidas en la suplicaçión puesta por los dichos regidores e repetidas por el dicho teniente en la respuesta de vn testimonyo. Y respondiendo a ellas digo que la merçed que vuestra alteza me hizo del dicho ofiçio fue justamente hecha y el dicho Christóual Aryas, cuyo hera el dicho ofiçio, le renunçió en mí líbremente, más avnque yo le conprara dél no por eso tengo pena ny él en venderlo pues de derecho no está proibido ni ay premática que tal diga.

$\mathrm{Y}$ en ser yo reçibido en el dicho ofiçio no se haze perjuizio a los buenos vsos de la çibdad de Cádiz porque no ay en ella priuilegio ni vso ni costunbre que los escriuanos sean della naturales antes todos los escriuanos del número que ay en la dicha çibdad eçebto vno son estrangeros y Diego Sánchez, que es el procurador que sygue esta causa, vno de los dichos escriuanos, es natural de la çibdad de Xerez. Y avnque fuese verdad que la naturaleza se requiriesse nací yo en la dicha çibdad de Cádiz, syendo mi padre y mi madre allý vezinos.

No ay oprobio ninguno de la dicha çibdad en que yo sea escriuano del número della pues soy ábile e sufiçiente y niego yo ser christiano nueuo, antes al tienpo que yo nasçí mi padre e mi madre heran convertidos a nuestra Santa fee cathólica y aún diez años antes. Y ésta que se allega no es causa bastante ${ }^{190}$ en derecho para quitarme a mí la merçed que vuestra alteza me tyene hecha pues en estos reynos no ay christiano que se pueda dezir nueuo.

Yo no soy ni nunca fuy de corona y afirmar lo contraryo es yntentar cabsas generales por donde se ynpida la merçed $/ /{ }^{19 \mathrm{v}}$ que vuestra alteza justamente me tiene fecha.

El dicho Christóual Arias nunca cometió delito por donde meresçiese ser priuado deste ofiçio, y avnque le cometiera antes que por sentençia fuese pronusçiado pudo muy bien renunçiar el dicho ofiçio.

El dicho ofiçio de escriuanía no es acreçentado y avnque lo fuera pues el dicho Christóual Aryas fue reçebido a él yo no puedo ser escluso, espeçialmente, no vacando por muer-

188. Al carecer de fecha el escrito alegatorio, hemos reseñado la data de su presentación ante el Consejo Real.

189. Bajo la dirección: Responde Diego González a la suplicaçión que hizo el procurador de la çibdad.

190. Tachado: para qui. 
te y la dicha çibdad se a perjudicado porque ha reçebido otros muchos [...] vacaçiones syn ayudarsse del dicho acresçentamiento.

La verdad es que el dicho regimiento y teniente no se mouieran a contradezir esta merçed sy no fueran movidos e rogados por vn Christóual Marrufo, que es vno de los dichos regidores, el qual tiene vn pariente muy çercano que es escriuano de la dicha çibdad y, por amystad que tiene al dicho escriuano y ene[mistad que] tiene a mý, negoçió con los dichos regidores de $[\ldots]$ que contradixesen la dicha merçed y diesen un poder con [...] y los escriuanos se obligaron de enbiar aquí a esta [...] que lo syg[uiese a su] costa. Y ansý lo han enbiado y publican que allegan estos ca[pítulos] por ser reçibidos a prueua y traerme vn año en pleito hasta destruyrme. A lo qual vuestra alteza no deue mandar dar lugar.

Pido e suplico a vuestra alteza me mande dar la dicha sobrecarta con pena y sy las causas que alegan fueren verdaderas quédeles su derecho a sa[lvo] para que lo sygan contra mý, que yo estoy presto destar con ellos a justiçia y padesçer las penas que la carta de vuestra alteza me ponen.

Para lo qual el real ofiçio de vuestra alteza ynploro, las costas pido y protesto $^{191}$.

$[1514 \text {, diciembre, } 14]^{192}$.

Diego Sánchez, procurador de Cádiz, pide a la reina, respondiendo a la alegación de Diego González, que atienda la suplicación de la ciudad por las razones esgrimidas.

AGS, CRC, 24, 7, Cuad ${ }^{\circ}$ 1, f. 23r-v.

$(\mathrm{Cruz})$

Muy poderosa señora ${ }^{193}$.

Diego Sánchez, en nombre del concejo, justicia, regidores de la ciudad de Cádiz, respondiendo a la petición presentada por el dicho Diego Gonçález, digo que no me apartando del seguimiento que tengo fecho en que supliqué mandasen legitimar su persona y no le oyr hasta que fuese proveído de curador ad liten, alegando más largamente del derecho de mis partes, digo que, sin embargo de lo en la dicha petición contenido, vuestra alteza debe fazer en todo según como por mí de suso está pedido e suplicado por lo siguiente:

- Lo primero porque de la dicha carta fue suplicado en tienpo e en forma y por cabsas muy bastantes y fueron fechas las diligençias nesçesarias.

- Lo otro porque el dicho Diego Gonçález padesçe los defetos que he dicho, no es vezino de la dicha cibdad ni lo fue su padre ni natural de ella, como se requiere.

- Lo otro porque es christiano nuevamente convertido de judío o, a lo menos, lo fue su padre y muchacho de poca hedad y persona raes y que segúnd los privilegios de la dicha cibdad no puede ser escriuano en ella.

- Lo otro porque siendo incapaz para poder usar del dicho ofiçio le conpró, y esta es causa bastante para le privar dél pues ay la misma razón que en los otros ofiçios públicos vedados por la premática que no se venda.

- Lo otro porque el dicho Christóval Arias tenía dispusición e abilidad para usar el dicho ofiçio y por le aver renunçiado sin liçençia de vuestra alteza le perdió según

191. En el ángulo inferior izquierdo: Diego González, escriuano público de número de Cádiz.

192. Al carecer de fecha el escrito alegatorio, hemos reseñado la data de su presentación ante el Consejo Real.

193. Bajo el tratamiento: replica el procurador de la çibdad. 
las leyes de estos reinos y la provisión que se dio devió ser obedesçida y no cunplida, como se hizo.

- Lo otro porque hizo la dicha renunçiaçión en fraude y por çierto delito de falsedad que cometió sabiendo que estava provada y esperaba ser acusado de eso.

- Lo otro porque el dicho Diego Gonçález es de corona como esta dicho.

- Lo otro porque el dicho ofiçio es acresçentado, deve ser consumido. Y niego aver resçebido mis partes otros que ayan seydo proveídos de ofiçios acresçentados.

- Lo otro porque la dicha çibdad y justiçia y regidores, mis partes, lo han contradicho por conservaçión de sus privilegios y por el bien público de la dicha çibdad y tratantes en ella donde //23v. se requieren escriuanos de mucha abtoridad y buena fama y fidelidad y no de la calidad que es el dicho Diego Gonçález.

Por ende, pido cunplimiento de justiçia, según faze y para ello vuestro real ofiçio ynploro y las costas pido y protesto y ofréscome a provar lo nesçesario y negando lo prejudiçial concluyo (rúbrica).

1568, octubre, 2. Sanlúcar de Barrameda.

Hernando de la Cruz, natural de Sanlúcar de Barrameda, pide a Luis Barba, corregidor de Sanlúcar, que apruebe las preguntas del examen de testigos para la información que remitirá al Consejo Real al pretender una escribanía de número de Jerez de la Frontera y otra de los reinos. El corregidor las aprueba y emite juicio favorable.

AGS, CJH, 37-121, s.f.

\section{$(\mathrm{Cruz})$}

$\mathrm{En}^{194}$ la villa de Sanlúcar de Barrameda, dos días del mes de otubre, año del nasçimiento de Nuestro Salvador Ihesuchristo de mill e quinientos e sesenta e ocho años.

Ante el muy magnífico señor, el liçençiado, Luis Barba, del Consejo del duque, nuestro señor, y corregidor e justiçia mayor en esta dicha villa por su exçelençia, y en presençia de mí, Diego de Sevilla, escriuano público desta dicha villa por su exçelençia, y de los testigos de yuso escritos, paresçió Hernando de la Cruz, natural desta villa, e presentó un escrito de pedimiento e çiertas preguntas, que su tenor del qual es este que se sigue:

Muy Magnífico señor. Hernando de la Cruz, natural desta villa de Sanlúcar de Barrameda, digo que yo pretendo suplicar a su Magestad me haga la merçed de vn ofisçio de escrivanía pública de la çibdad de Xerez de la Frontera e para que sea su escriuano e notario público en la su corte y en todos los sus reynos. E para que a su Magestad e a los señores de su muy alto Consejo conste, tengo nesesidad se aya ynformaçión cómo en mí concurren las calidades en derecho nesçesarias, pido a vuestra merçed que a los testigos que presentare se esaminen por los artículos siguientes e lo que dixeren e depusieren me lo mande dar en pública forma, ynterponiendo vuestra merçed a ello su avtoridad e decreto judiçial para que valga e haga fee en juizio e fuera dél e pido justicia.

194. En la hoja de portada: (Cruz) Hernando de la Cruz. En Madrid, siete de enero de IUDLXX años, se exsaminó. 
Primero si conosçen a mí, el dicho Hernando de la Cruz, e si conosçieron a Antón de la Cruz, escriuano público que fue desta villa, difunto, e si conosçen a Leonor López, padre e madre del dicho Hernando de la Cruz, // todos vezinos desta villa, e si conosçieron a Gonzalo de Llerena e a Juana Hernández, su muger, padres del dicho Antón de la Cruz, y Hernán López y Françisca López, su muger, padres de la dicha Leonor López, que ya son difuntos.

Sy saben que los dichos Antón de la Cruz y Leonor López, su muger, fueron marido e muger, casados e velados legítimamente, según orden de la santa madre Yglesia, e que como tales marido e muger hizieron vida maridable en vno en esta villa donde heran veçinos y en esta posesión fueron avidos e tenidos e comúnmente reputados y que ésta es pública boz y fama.

Yten si saben que durante el matrimonio entre los susodichos ovieron e proqrearon por su hijo legítimo y natural al dicho Hernando de la Cruz e como tal lo criaron, trataron e nonbraron e alimentaron, llamándolo hijo y él a ellos padres y en esta posesión hes avido e tenido e así es pública boz e fama e comúnd opinión entre las personas que dello tienen notiçia e conosçimiento, digan lo que saben.

Si saben que el dicho Antón de la Cruz fue escriuano público en esta dicha villa de Sanlúcar más tienpo de treynta años hasta el día que fallesçió e quel dicho Hernando de la Cruz, su hijo, dende que tuvo hedad e supo escrivir estuvo e residió en el ofisçio y escrivanía del dicho su padre, escriviendo e vsando y exerçiendo el dicho ofisçio e después que fallesçió a estado en otros ofiçios públicos en esta dicha villa y en la çibdad de Xerez de la Frontera e otras partes e a resydido en ello hordinariamente, digan lo que saben. //

E presentada la dicha petiçión, como dicho es, el dicho señor corregidor dixo que mandava e mandó que se le dé la dicha provança autorizada, como lo pide, y en lo demás que su merçed conosçe al dicho Hernando de la Cruz de más de diez años a esta parte, que es hijo de Antón de la Cruz, escriuano público que fue desta villa, e dende niño se a criado en el ofisçio de escriuano. E de seys años a esta parte le a visto vsar ofisçio de tal escriuano e ordenar e hazer escripturas públicas e contratos e otras cosas tocantes a ofisçio de escriuano. E sabe ques legal e verdadero e porque ante su merçed, como corregidor desta villa, a vsado el dicho ofisçio y a dado muy buena qüenta dél e que su Magestad, siendo servido, le podrá hazer merced de darle título de escriuano real de su Magestad para que en todos los sus reynos pueda vsar el dicho ofisçio. Y así lo dixo e se lo mandó dar por testimonio y lo firmó de su nonbre.

Testigos: Juan de Bolaños, escriuano del cabildo, y el liçençiado Alonso de Ávila, veçinos desta villa, el Liçençiado Aranda. Christóval de Yepes, escriuano público.

El Liçençiado Aranda (rúbrica).

En testimonio de verdad yo, el dicho escriuano público, lo fize escribir e fize aquí mi sig(signo)no e soy testigo. Christóval de Yepes, escriuano público (rúbrica). 


\section{Anexo}

Renuncias y vacantes en los oficios notariales de Cádiz (1499-1542)

\begin{tabular}{|l|l|l|l|l|}
\hline & \multicolumn{2}{|c|}{ RENUNCIA } & \multicolumn{2}{c|}{ VACANTE } \\
\hline Fecha título sucesor & Renunciante & Renunciatario & Notario fallecido & Notario sucesor \\
\hline$[$ ca. 1499.09 .30$]$ & & & Pedro Galíndez & Juan de Amar, su hijo \\
\hline 1502.08 .22 & Diego López & Fernando Sánchez de Alcaraz & & \\
\hline 1509.04 .3 & Nuño Fernández de Villavicencio & Rodrigo de Arenas & & \\
\hline 1510.11 .2 & Juan Cestón & Juan de Oviedo & & \\
\hline 1511.03 .8 & Sancho Benítez & Hernando Gascón & & \\
\hline 1511.04 .15 & Juan de Oviedo & Lope de Medina & & \\
\hline 1511.06 .4 & Rodrigo de Arenas & Cristóbal Arias & & \\
\hline 1511.06 .20 & Juan de Haya & Juan de Alcalá & & \\
\hline 1512.02 .14 & Juan de Alcalá & Diego Ramírez de la Rúa & & \\
\hline 1513.02 .4 & Antón Romí & Francisco de Mayorga & & \\
\hline 1513.05 .20 & Alonso de Polanco & Luis de León & & \\
\hline 1513.05 .22 & Francisco Gastón & Diego Sánchez & & \\
\hline 1514.09 .25 & Cristóbal Arias & Diego González & & \\
\hline 1515.03 .13 & Juan de Amar & Gonzalo García & & \\
\hline 1520.03 .3 & Luis de León & Alonso de Medina & & \\
\hline
\end{tabular}

195. Las datas son las de los títulos de los beneficiarios, renunciatarios y sucesores, AGS, RGS, Inventario 62, vols. 1-3. Los datos del primer registro en Apéndice, doc $\mathrm{n}^{\circ} 1$ 


\begin{tabular}{|c|c|c|c|c|}
\hline 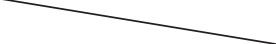 & \multicolumn{2}{|c|}{ RENUNCIA } & \multicolumn{2}{|c|}{ VACANTE } \\
\hline Fecha título sucesor & Renunciante & Renunciatario & Notario fallecido & Notario sucesor \\
\hline 1524.07 .8 & Gonzalo García & Manuel Ferraz, yerno & & \\
\hline 1526.03 .16 & Diego Ramírez & Cristóbal Díaz & & \\
\hline 1526.09 .13 & Cristóbal Díaz & Diego Ramírez & & \\
\hline 1530.11 .28 & Fernán Sánchez & Felipe Sánchez, hijo & & \\
\hline 1534.03 .23 & Felipe Sánchez & Luis Vivián & & \\
\hline 1537.10 .7 & & & Diego Sánchez & Diego Pérez de Lequeito \\
\hline 1538.03 .16 & Diego Pérez de Lequeito & Diego de Padilla & & \\
\hline 1540.03 .6 & Diego de Padilla & Diego Pérez de Lequeito & & \\
\hline 1540.5 .18 & Diego Pérez de Lequeito & Simón García Copín & & \\
\hline 1540.12 .20 & Manuel Fernández & Antonio Portillo & & \\
\hline 1541.03 .12 & Antonio Portillo & Manuel Fernández & & \\
\hline 1542.06 .25 & Diego González & Juan Barrera & & \\
\hline
\end{tabular}




\section{BiBLIOGRAFÍA CITADA}

Antón Solé, Pablo; Ravina Martín, Manuel (1975), Catálogo de documentos Medievales del Archivo Catedralicio de Cádiz. 1263-1500, Cádiz.

Arroyal Espigares, Pedro Juan; Martín Palma, María Teresa; Cruces Blanco, María Ester (1991), Las escribanías públicas de Málaga (1487-1516), Málaga.

Arroyal Espigares, Pedro Juan; Martín Palma, María Teresa; Cruces Blanco, María Ester (1995), "Sobre los orígenes de la institución notarial en Málaga", Ostos Salcedo, Pilar y Pardo Rodríguez, María Luisa, El Notariado andaluz en el tránsito de la Edad Media a la Edad Moderna. I Jornadas sobre el Notariado en Andalucía, Sevilla, pp. 47-73.

Blasco Martínez, Rosa María (1991), Una aproximación a la institución notarial en Cantabria, Santander.

Bono Huerta, José (1982), Historia del Derecho notarial Español, vol. I-2, Madrid.

Bono, José; Ungueti, Carmen (1986), Los protocolos sevillanos de la época del descubrimiento, Sevilla.

Bono Huerta, José (1990), Breve introducción a la Diplomática notarial española (Parte 1), Sevilla.

Carmona de los Santos, María; Parera Fernández-Pacheco, María Esperanza (1977), Índices de los protocolos notariales del Archivo Histórico Provincial de Cádiz, Cádiz.

Carracedo Falagán, Carmen (1990), “El escribano municipal según una información enviada al Consejo de Castilla el año 1626: requisitos legales para ejercer el oficio", Boletin del instituto de estudios asturianos, 133, pp. 45-72.

Carrasco García, Gonzalo (2006), "Judeoconversos de Jerez y el obispado de Cádiz a fines del siglo XV", En la España Medieval, 29, pp. 326-328.

Crespo Muñoz, Francisco Javier (2007), El notariado en Baza (Granada) a comienzos de la edad moderna. Estudio y catálogo de los protocolos notariales (1510-1519), Granada, Universidad, Facultad de Filosofía y Letras, Departamento de Historia Medieval y Ciencias y Técnicas Historiográficas, (tesis doctoral), http://hdl.handle.net/10481/1575 [consulta: 06/05/2018].

Diccionario de Autoridades (1979), 3 vols., Madrid.

Domínguez Guerrero, María Luisa (2016), Las escribanías públicas en el antiguo Reino de Sevilla bajo el reinado de Felipe II (1556-1598), Sevilla, Universidad, Facultad de Filosofía y Letras, Departamento de Historia Medieval y Ciencias y Técnicas Historiográficas, (tesis doctoral), http://hdl.handle. net/11441/52256 [consulta: 17/05/2018].

Domínguez Ortiz, Antonio (1991), La clase social de los conversos en Castilla en la Edad Moderna, Granada.

Edwards, John (1990), “"Raza» y religión en la España de los siglos XV y XVI: una revisión de los estatutos de «limpieza de sangre»”, Anales de la Universidad de Alicante: Historia medieval, 7, pp. 243-261.

Escalante Jiménez, José (2015), Los escribanos en Antequera. Un análisis global (1475-1869), Málaga, Universidad, Facultad de Filosofía y Letras, Departa- 
mento de Historia Moderna y Contemporánea, (tesis doctoral), https://riuma. uma.es/xmlui/handle/10630/10127 [consulta: 05/05/2018].

Extremera Extremera, Miguel Ángel (2009), El notariado en la España Moderna. Los escribanos públicos de Córdoba (siglos XVI-XIX), Córdoba.

Franco Silva, Alfonso (2010), El condado de Oropesa y otros estudios de Historia Medieval, Jaén.

García Goyena, Florencio; Aguirre, Joaquín (1841), Febrero o Librería de jueces, abogados y escribanos: comprensiva de los Códigos civil, criminal y administrativo... Parte civil, Madrid, vol. VI, Tít LXXII.

Gil Fernández, Juan (2000-2002), "Dos padrones de conversos en Sanlúcar de Barrameda", Excerpta philologica. Iosepho ludovico Pereira Iglesias Sacra, vols. 10-12, Cádiz, pp. 485-515.

Gil Fernández, Juan (2003), Los conversos y la Inquisición sevillana. VIII. Apéndices, Sevilla, 2003.

González Alonso, Benjamín (1980), "La fórmula “Obedézcase pero no se cumpla" en el Derecho castellano de la Baja Edad Media", Anuario de Historia del Derecho Español, 50, pp. 469-488.

González Jiménez, Manuel (2006), Carmona medieval, Sevilla.

Hernández Benítez, Mauro (1995), "Y después de la ventas de oficios ¿Qué? (Transmisiones privadas de regimientos en el Madrid Moderno, 1606-1808", Anuario de Historia del Derecho Español, 65, Madrid, pp. 705-748.

Labrador Arroyo, Felix (2000), "Las dimensiones del servicio de la emperatriz Isabel”, Martínez Millán, José, La Corte de Carlos V, $1^{\text {a }}$. Parte, vol. II-3, Madrid, pp. 93-96.

Libro de las Bulas y Pragmáticas de los Reyes Católicos (1973), T. II, Madrid.

López Belinchón, Bernardo (1998), "La memoria de la infamia”, Martínez Millán, José, Felipe II (1598-1998), Europa dividida, la monarquía católica de Felipe II, vol. 3, Madrid, pp. 271-290.

López Beltrán, María Teresa (2006), "Perfil de un judeoconverso del Reino de Granada: El escribano Antón López de Toledo", Revista del Centro de Estudios Históricos de Granada y su Reino, 18, pp. 53-76.

Martín Gutiérrez, Emilio (2006), "Nuevos datos sobre la población y los genoveses en la ciudad de Cádiz. Una relectura del padrón de vecinos de 1467”, En la España Medieval, 29, pp. 187-223.

Martínez Carrillo, María de los Llanos (2002), "Escribanos e inquisición en los finales del siglo XV murciano", Marsilla de Pascual, Francisco, Littera scripta in honorem Prof. Lope Pascual Martínez, Murcia, vol. 2, pp. 597-609.

Moreno Trujillo, María Amparo (1995), "Diplomática Notarial en Granada (15051520)”, Ostos Salcedo, Pilar y Pardo Rodríguez, María Luisa, El Notariado andaluz en el tránsito de la Edad Media a la Edad Moderna. I Jornadas sobre el Notariado en Andalucía, Sevilla, pp. 75-125.

Moreno Trujillo, María Amparo (2010), "Las actuaciones de la inquisición y los escribanos judeo conversos del entorno del conde de Tendilla", Historia. Instituciones. Documentos, 37, 181-210. 
Nueva Recopilación de las leyes destos reynos, hechas por mandado de la Magestad Católica del rey don Felipe Segundo Nuestro Señor (1640), 3 vols., Madrid.

Obra Sierra, Juan María de la (1995), “Aproximación al estudio de los escribanos públicos del número en Granada (1497-1520)”, Ostos Salcedo, Pilar y Pardo Rodríguez, María Luisa, El notariado andaluz en el tránsito de la Edad Media a la Edad Moderna. I Jornadas sobre el Notariado en Andalucía, Sevilla, pp. 127-170.

Obra Sierra, Juan María de la (2011), "Los registros notariales castellanos", Cantarell Barella, Elena y Comas Via, Mireia, La escritura de la memoria: los registros, Barcelona, pp. 73-110.

Obra Sierra, Juan María de la; Moreno Trujillo, María Amparo (2012), "La práctica notarial posterior a la Pragmática de Alcalá: unos cuadernos de notas de Baza (1535)", Marín López, Rafael, Homenaje al profesor Dr. D. José Ignacio Fernández de Viana y Vieites, Granada, pp. 352-368.

Ostos Salcedo, Pilar (1994), "Diplomática notarial en la época colombina: Fases de redacción y forma documental", Piergiovanni, Vito, Tra Siviglia e Genova: notaio, documento e commercio nell'età colombiana. Atti del Convegno internazionale di studi storici per le celebrazioni colombiana, Milán, pp. 198-204.

Ostos Salcedo, Pilar (1995), "Los escribanos públicos de Córdoba en el tránsito de la Edad Media a la Edad Moderna", Ostos Salcedo, Pilar y Pardo Rodríguez, María Luisa, El notariado andaluz en el tránsito de la Edad Media a la Edad Moderna. I Jornadas sobre el Notariado en Andalucía, Sevilla, pp. 201-256.

Ostos Salcedo, Pilar (1998), “Aranceles notariales de Córdoba (1482-1495)”, Historia. Instituciones. Documentos, 25, Sevilla, pp. 503-524.

Ostos Salcedo, Pilar (2014), "El documento notarial en Andalucía”, Ostos Salcedo, Pilar, Práctica notarial en Andalucía (siglos XIII-XVII), Sevilla, pp. 15-31.

Pardo Rodríguez, María Luisa (1994), "Notariado y cultura en la época colombina", Piergiovanni, Vito, Tra Siviglia e Genova: notaio, documento e commercio nell'età colombiana. Atti del Convegno internazionale di studi storici per le celebrazioni colombiana, Milán, pp. 145-186.

Pardo Rodríguez, María Luisa (1995), "El notariado de Sevilla en el tránsito a la Modernidad", Ostos Salcedo, Pilar y Pardo Rodríguez, María Luisa, El Notariado andaluz en el tránsito de la Edad Media a la Edad Moderna. I Jornadas sobre el Notariado en Andalucía, Sevilla, pp. 257-291.

Pardo Rodríguez, María Luisa (1998), “Aranceles de escribanos públicos de Sevilla”. Historia. Instituciones. Documentos, 25, Sevilla, pp. 525-536.

Partidas (1972): Las Siete Partidas del rey don Alonso el Sabio, 3 vols., Madrid.

Porras Arboledas, Pedro Andrés (2008a), Comercio, banca y judeoconversos en Jaén, 1475-1540, Jaén.

Porras Arboledas, Pedro Andrés (2008b), Las comunidades conversas en Úbeda y Baeza en el siglo XVI.

Quevedo Sánchez, Francisco (2015), Familias en movimiento. Los judeoconversos cordobeses y su proyección en el Reino de Granada (ss. XV-XVII), Gra- 
nada, Universidad, Facultad de Filosofía y Letras, Departamento de Historia Medieval y Ciencias y Técnicas Historiográficas, (tesis doctoral), http://hdl. handle.net/10481/43675 [consulta: 06/05/2018].

Ramírez Barrios, Julio Alberto (2015), "El concejo de Carmona y el nombramiento de escribanos: conflictos con el poder regio", Pueyo Colomina, Pilar, Lugares de escritura: la ciudad. XII Jornadas de la SECCTTHH, Zaragoza, pp. 305-308.

Rodríguez Adrados, Antonio (1988), "La Pragmática de Alcalá, entre las Partidas y la Ley del Notariado", Homenaje a Juan Berchmans Vallet de Goytisolo, 7, Madrid, pp. 517-813.

Rojas García, Reyes (2015), La práctica de los escribanos públicos de Sevilla: los manuales (1504-1550), Sevilla.

Rojas Vaca, María Dolores (1995), "Notariado público y documento notarial en Jerez de la Frontera en el tránsito a la modernidad", Ostos Salcedo, Pilar y Pardo Rodríguez, María Luisa, El Notariado andaluz en el tránsito de la Edad Media a la Edad Moderna. I Jornadas sobre el Notariado en Andalucía, Sevilla, pp. 293-338.

Rojas Vaca, María Dolores (1996), El Documento Marítimo-Mercantil en Cádiz (1550-1600). Diplomática notarial, Cádiz.

Rojas Vaca, María Dolores (2006), "El documento notarial de Castilla en época Moderna", Marsilla de Pascual, Francisco, Diplomática antigua. Diplomática moderna. III Jornadas de la SECCTTHH, Boletín de la Sociedad Española de Ciencias y Técnicas Historiográficas, 3, Murcia, pp. 65-126.

Rojas Vaca, María Dolores (2007), "Los procuradores del número de Cádiz y la Hermandad de Nuestra Señora del Pópulo (1617)", Escritura y documentos. Los archivos como fuentes de información, León, pp. 436-473.

Rojas Vaca, María Dolores (2010), "Las escribanías del cabildo municipal en Jerez de la Frontera (1514-1615)», Historia. Instituciones. Documentos, 37, Sevilla, pp. 283-336.

Rojas Vaca, María Dolores (2014), "Jerez de la Frontera: privilegio, uso y costumbre en el nombramiento de escribanos del número", Barea Rodríguez, Manuel y Romero Bejarano, Manuel, 750 aniversario de la incorporación de Jerez a la Corona de Castilla: 1264-2014), Jerez de la Frontera, pp. 577-602.

Sánchez Herrero, José (1981), Cádiz. La ciudad medieval y cristiana (1260-1525), Córdoba.

Sancho de Sopranis, Hipólito (1953), "La judería del Puerto de Santa María de 1483-1492", Sefarad: Revista de Estudios Hebraicos y Sefardies, 13, 2, pp. 309-324.

Tau Anzoátegui, Victor (1980), “La ley 'se obedece pero no se cumple'; en torno a la suplicación de las leyes en el derecho indiano", Anuario histórico-jurídico ecuatoriano, 6, pp. 55-110.

Tomás y Valiente, Francisco (1970), “Origen bajomedieval de la patrimonialización y la enajenación de los oficios públicos en Castilla”, Actas del I Symposium de Historia de la Administración, Madrid, pp. 125-139. 
Tomás y Valiente, Francisco (1982a), La venta de oficios en Indias (1492-1606), Madrid.

Tomás y Valiente, Francisco (1982b), "Ventas de oficios públicos en Castilla durante los siglos XVII y XVIII", Gobierno e instituciones en la España del Antiguo Régimen, Madrid, pp. 151-177.

Tomás y Valiente, Francisco (1993), "La venta de oficios en Indias y en particular la de escribanías", Escribanos y Protocolos notariales en el descubrimiento de América, Madrid, pp. 95-103. 